\title{
Effect of Land Use Changes on Carbon Stock Dynamics in Major Land Use Sectors of Mizoram, Northeast India
}

\author{
Soibam Lanabir Singh, Uttam Kumar Sahoo*, Anudip Gogoi, Alice Kenye \\ Department of Forestry, School of Earth Sciences \& Natural Resource Management, Mizoram University, Aizawl, India \\ Email: *uksahoo_2003@rediffmail.com, *uttams64@gmail.com, lanabir@gmail.com, mzunudeep@gmail.com, \\ alicekenye123@gmail.com
}

How to cite this paper: Singh, S.L., Sahoo, U.K., Gogoi, A. and Kenye, A. (2018) Effect of Land Use Changes on Carbon Stock Dynamics in Major Land Use Sectors of Mizoram, Northeast India. Journal of Environmental Protection, 9, 1262-1285. https://doi.org/10.4236/jep.2018.912079

Received: October 15, 2018

Accepted: November 10, 2018

Published: November 13, 2018

Copyright (c) 2018 by authors and Scientific Research Publishing Inc. This work is licensed under the Creative Commons Attribution International License (CC BY 4.0).

http://creativecommons.org/licenses/by/4.0/

\begin{abstract}
Land use change activities have greatly affected the total ecosystem carbon stock (TECS) and also contribute to global change through emission of greenhouse gases. The present study assessed the change in vegetation biomass carbon stock (VBCS) and soil organic carbon stock (SOCS) following conversion in major land use sectors (agriculture, agroforestry, forest and plantation) in Mizoram, Northeast India. SOCS was the highest in agroforestry (50.85 $\mathrm{Mg} \mathrm{C} \mathrm{ha}^{-1}$ ) and the lowest in agriculture (33.99 $\left.\mathrm{Mg} \mathrm{C} \mathrm{ha}^{-1}\right)$. VBCS was the highest in plantation (131.66 $\mathrm{Mg} \mathrm{C} \mathrm{ha}^{-1}$ ) and the lowest in agriculture $\left(7.44 \mathrm{Mg} \mathrm{C} \mathrm{ha}^{-1}\right)$. The highest positive TECS change rate was observed when agriculture was converted to plantation $\left(6.61 \mathrm{Mg} \mathrm{C} \mathrm{ha}{ }^{-1} \cdot \mathrm{yr}^{-1}\right)$, while negative rate of change in carbon stock was observed following the establishment of agriculture from other land use. A positive rate of change was observed in both VBCS and SOCS with TECS rate of $3.58 \mathrm{Mg} \mathrm{C} \mathrm{ha}{ }^{-1} \cdot \mathrm{yr}^{-1}$ when agriculture got converted to agroforestry. The absolute carbon stock change rates were higher in VBCS than SOCS signifying the importance to maintain tree based vegetation cover.
\end{abstract}

\section{Keywords}

Land Use Change, Soil Organic Carbon Stock, Vegetation Biomass Carbon Stock

\section{Introduction}

Greenhouse gas (GHG) emissions from land-use, land-use change and forestry (LULUCF) activities substantially increased [1] [2] [3] and these land use 
changes, mainly deforestation accounts for $12 \%$ - $20 \%$, to be the second largest source of anthropogenic GHG emissions [4]. The alarming rate of GHG increase held responsible for ongoing climate change has consequently drawn research attention associated with land use changes [5] [6] [7]. Carbon storage in different pools (live biomass, litter, deadwood and soil) were directly affected by land use change [8] and its rate of change varies in accordance to climatic responses, vegetative cover, choice of species, management practices and anthropogenic interventions [9] [10]. Hence, past and current land use practices stand out as an indicator either to be carbon sinks or source [11]. Carbon stock in both vegetation and soil have been reported to loss following conversion of primary forest to secondary forest [12] [13], and several other studies also reported variations either a gain or loss of carbon stock associated with land use change in diverse ecosystems [14] [15] [16] [17]. Several initiatives have been reported to reduce anthropogenic carbon emission form land use change with adoption of scientific land use management practices such as tree buffer plantations around farmlands, mulching and soil enrichment fertilizer applications, forest slash and crop residue retention, elongation of fallow periods in shifting cultivation, crop rotation and tree plantation in degraded areas [18]. However, studies on carbon stock changes associated with the wide range of prevailing land use types following conversions in Mizoram, Northeast India have been lacking behind and no importance was given to the carbon implications of various land uses before making land use change decisions. This necessitates the present study to assess ecosystem carbon stock in different land use types and stock change rate following conversions in major land use sectors. The study further aims to monitor carbon pool dynamics following land use changes and provide scientific knowledge to support policy decision making for land use change planning and enhance the regional carbon stocks overall as an option for climate change mitigation.

\section{Materials and Methods}

\subsection{Study Sites}

The study was undertaken in Mizoram, Northeast India which lies between $21^{\circ} 58^{\prime}$ to $24^{\circ} 35^{\prime} \mathrm{N}$ and $91^{\circ} 15^{\prime}$ to $93^{\circ} 29^{\prime} \mathrm{E}$ with a geographical area of $21,081 \mathrm{~km}^{2}$. The elevations ranges 40 to $2157 \mathrm{~m}$ above sea level from the western (Bairabi valley) to eastern side (Phawngpui). Annual rainfall averages $2500 \mathrm{~mm}$ occurring between May to October while December and January are the driest months. Temperature varies from about $11^{\circ} \mathrm{C}$ in winter to $30^{\circ} \mathrm{C}$ in summer or spring. Based on interpretation of satellite data, the forest cover of Mizoram is $18186 \mathrm{~km}^{2}$ with $131 \mathrm{~km}^{2}$ under very dense forest, $5861 \mathrm{~km}^{2}$ under moderately dense forest and $12194 \mathrm{~km}^{2}$ under open forest in terms of forest canopy density classes [19]. The state witnessed different predominant land use/land cover types such as Shifting cultivation (locally known as “jhum”)—Current Jhum (1091.11 $\mathrm{km}^{2}$ ) and Jhum fallow $\left(2869.30 \mathrm{~km}^{2}\right)$; Bamboo Forest $\left(6708.37 \mathrm{~km}^{2}\right)$; Forest plantation $\left(85.64 \mathrm{~km}^{2}\right)$; and Oil palm plantation $\left(233.58 \mathrm{~km}^{2}\right)$ responsible for 
forest cover reduction of $1054 \mathrm{~km}^{2}$ from 2009 to 2017 [20]. Shifting cultivation and plantation crops (oil palm, arecanut, teak, orange etc.) have widely replaced many of the native and bamboo forests. The government of Mizoram also promoted cultivation of these horticultural cash crops through various sponsored schemes at the cost of forest destruction and degradation. To estimate the difference in carbon stock among different land uses, we identified four major land use sectors in Mizoram, viz. 1) Agriculture, 2) Agroforestry, 3) Forest and 4) Plantation. Agriculture comprised of Current Jhum, Jhum Fallow and Wet Rice Cultivation; Agroforestry comprised of Old Homegarden and Young Homegarden; Forest comprised of Dense Forest, Open Forest, Bamboo Forest and Grassland; and Plantation comprised of Arecanut, Coffee, Mango, Oil Palm, Orange, Pine and Teak. A total of 38 sites distributed over 16 land use types were selected for the present study (Figure 1). The age of the different land use types were recorded from the landholders and villagers.

\subsection{Biomass Carbon Estimation}

Permanent plots $\left(250 \times 250 \mathrm{~m}^{2}\right)$ were set up in each of the selected land use types following ISRO-GBP/NCP-VCP protocol [21], and four nested sampling quadrats were laid in the corners. The permanent plot sizes were reduced to 100 $\times 100 \mathrm{~m}^{2}$ in land use types where land holding size was less than 2 ha. Nested quadrats size were of 0.1 ha $\left(31.62 \times 31.62 \mathrm{~m}^{2}\right)$ for estimating tree and deadwood; two quadrats of size $5 \times 5 \mathrm{~m}^{2}$ to estimate saplings/shrub/bamboo; and four quadrats of size $1 \times 1 \mathrm{~m}^{2}$ for herbs and standing litter (Figure 2). All trees

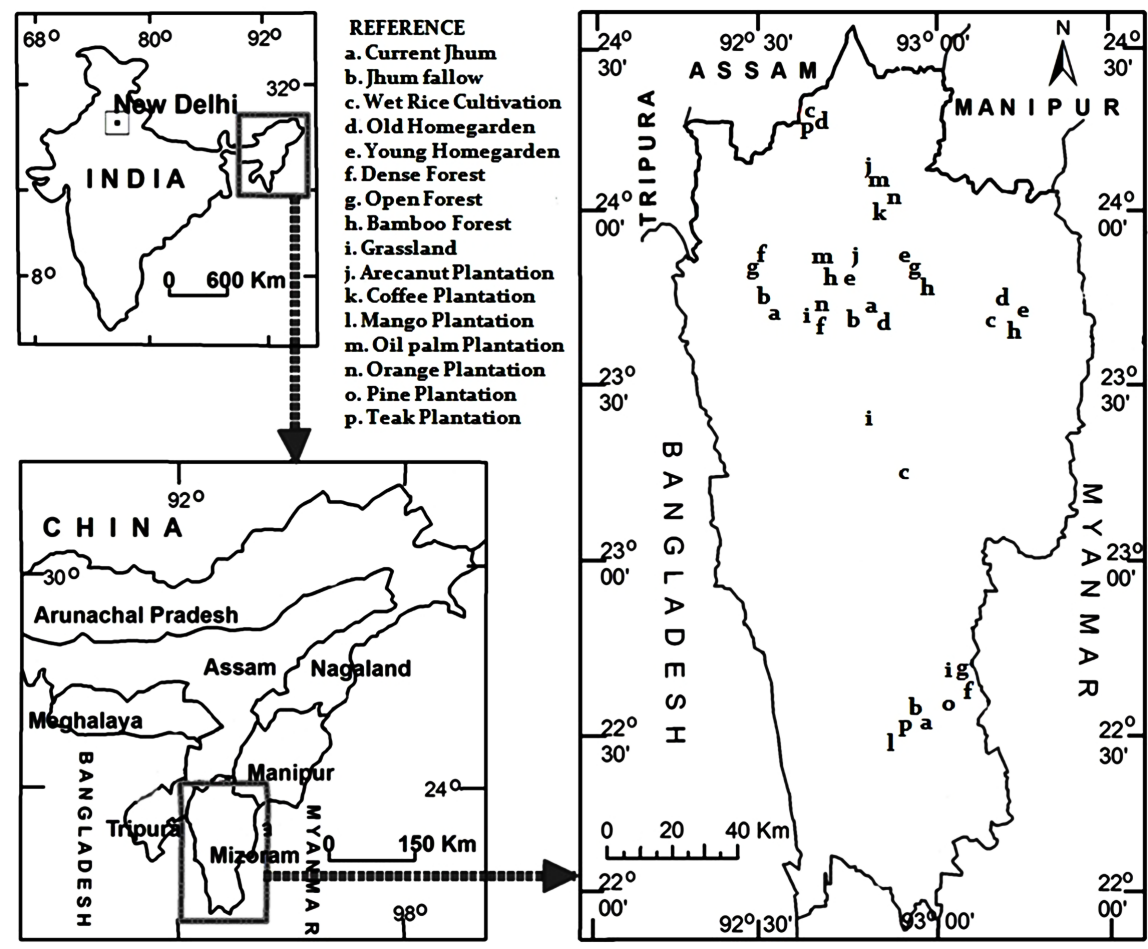

Figure 1. Location of the selected different land use types in Mizoram, Northeast India. 


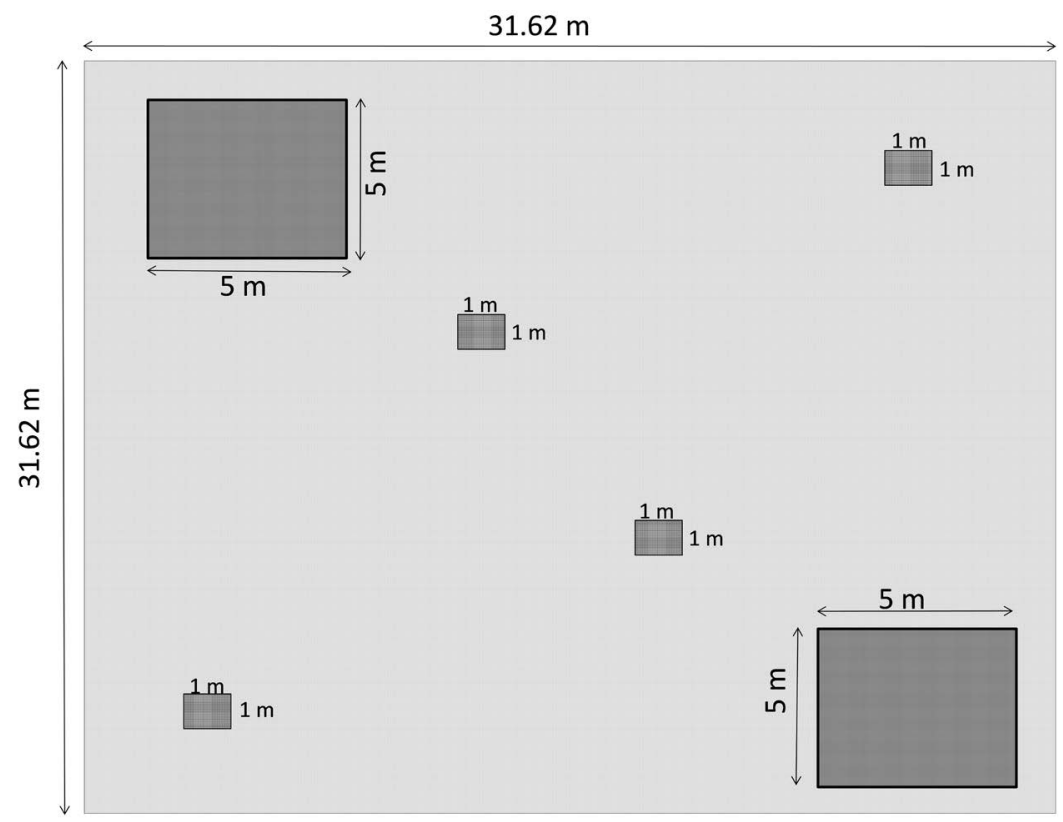

Figure 2. Nested quadrats scheme for sampling: Trees \& Deadwood $(31.62 \times 31.62 \mathrm{~m})$; Saplings/Shrubs/Bamboo $(5 \times 5 \mathrm{~m}, 2$ nos. $)$; and Herbs \& Litter $(1 \times 1 \mathrm{~m}, 4$ nos. $)$.

greater than $30 \mathrm{~cm}$ girth over bark at breast height (GBH, $1.37 \mathrm{~m}$ above ground level) were identified and tagged, and were measured for GBH using a metal tape and height by use of Haga altimeter and measuring tape. All coarse deadwood biomass ( $>10 \mathrm{~cm}$ diameter) were recorded following fixed-area sampling (FAS) [22]. Collar diameter (5 $\mathrm{cm}$ above ground level) and height of all saplings and shrubs encountered were measured with digital vernier caliper and measuring tape respectively. Plant density $\left(\mathrm{ha}^{-1}\right)$ and basal area $\left(\mathrm{m}^{2} \cdot \mathrm{ha}^{-1}\right)$ was calculated from the expanded values of each nested plots and averaged for each land use type. Above ground biomass (AGB) and below ground biomass (BGB) were estimated using appropriate allometric models for the trees/deadwood and saplings/shrubs (Table 1). The specific wood density values of trees were adopted from the Global Wood Density Database [23]. Volume of deadwood was multiplied with determined values of its corresponding decay classes, viz. sound, partial and full decomposed considered as $0.45,0.35$ and $0.25 \mathrm{~g} \cdot \mathrm{cm}^{-3}$ respectively [24]. Bamboo biomass (Melocanna baccifera) was estimated by harvesting bamboo culms samples from different diameter classes and total bamboo biomass was estimated as the sum after multiplying dry biomass with the corresponding densities of its diameter class. The aboveground biomass of herbs and litter was estimated by harvest method [25]. All biomass measurements were converted to a per hectare basis $\left(\mathrm{Mg} \mathrm{ha}^{-1}\right)$.

\subsection{Soil Organic Carbon (SOC) Stock Estimation}

Physico-chemical characteristics of soil were analyzed with soil samples collected from the permanent plots for every land use type and each nested plot being laid. Sampling points ( 5 nos.) were randomly selected from which soils were collected 
Table 1. Summary of allometric equations used in the study.

\begin{tabular}{ccc}
\hline Biomass type & Equation & Reference \\
\hline Trees & $\mathrm{AGB}=0.0673 \times\left(\rho \mathrm{D}^{2} \mathrm{H}\right)^{0.976}$ & {$[26]$} \\
Banana & $\mathrm{AGB}=0.0303 \times \mathrm{D}^{2.1345}$ & {$[27]$} \\
Arecanut/Palm & $\mathrm{AGB}=4.5 \times 7.7 \times \mathrm{H}$ & {$[28]$} \\
Oil palm & $\mathrm{AGB}=71.797 \times \mathrm{H}-7.0872$ & {$[29]$} \\
Saplings/Shrubs & $\mathrm{AGB}=\exp (-3.5+1.65 \times \ln (\mathrm{CD})+0.842 \times \ln (\mathrm{H})$ & {$[30]$} \\
Root estimate & $\mathrm{BGB}=\exp (-1.085+0.9256 \times \ln (\mathrm{AGB}))$ & {$[31]$} \\
DW & $\mathrm{V}=\left(\mathrm{L} \times \pi \times \mathrm{D}_{m}^{2}\right) / 4$ & {$[32]$} \\
$\mathrm{DW}_{\text {oil }}$ pals frump & $\mathrm{CWD}=\left(220.08+0.16 \times \mathrm{W}_{f b} \times \mathrm{L}_{f}\right) / 1000$ & {$[33]$} \\
\hline
\end{tabular}

$\mathrm{AGB}=$ dry above ground biomass $(\mathrm{kg}) ; \rho=$ wood density $\left(\mathrm{g} \cdot \mathrm{cm}^{-3}\right) ; \mathrm{D}=$ diameter at breast height $(\mathrm{cm}) ; \mathrm{CD}$ $=$ collar diameter $(\mathrm{cm}) ; \mathrm{H}=$ total height $(\mathrm{m}) ; \mathrm{BGB}=$ below ground biomass $(\mathrm{kg}) ; \mathrm{DW}=$ Deadwood; $\mathrm{V}=$ volume $\left(\mathrm{cm}^{3}\right) ; \mathrm{D}_{m}=$ mid-diameter of the log/stump $(\mathrm{cm}) ; \mathrm{L}=$ Length or height of log/stump $(\mathrm{cm}) ; \mathrm{CWD}=$ Coarse Woody Debris $(\mathrm{kg}) ; \mathrm{W}_{f b}=$ Width of frond base $(\mathrm{cm}) ; \mathrm{L}_{f}=$ Length of frond $(\mathrm{cm})$.

at three depth classes: $0-15,15-30$ and $30-45 \mathrm{~cm}$. The five sub samples from each nested plot and depth class were mixed respectively to obtain one composite sample for each depth class with a total of 456 samples (38 land use $\times 4$ plots $\times 3$ depths $\times 1$ composite sample), which were air dried, lightly grounded and sieved through $2 \mathrm{~mm}$ mesh for SOC estimation by rapid titration method [34] [35]. A total of 456 samples (38 land use $\times 4$ plots $\times 3$ depths) for soil bulk density (BD) measurements were obtained by inserting the soil core horizontally at the middle of each soil depth class [36]. Soil Organic Carbon Stock $\left(\mathrm{Mg} \mathrm{C} \mathrm{ha}^{-1}\right)$ for each land use type and depth up to $45 \mathrm{~cm}$ were computed as follows [37]:

$$
\begin{aligned}
\mathrm{SOC} & =\sum_{\text {horizon=1 }}^{\text {horizon } n} \mathrm{SOC}_{\text {horizon }} \\
& =\sum_{\text {horizon=1 }}^{\text {horizn }=}([\mathrm{SOC}] \times \text { Bulk density } \times \text { Depth } \times(1-\text { frag. } .) \times 10)_{\text {horizon }}
\end{aligned}
$$

where, $\mathrm{SOC}=$ representative soil organic carbon stock, $\mathrm{Mg} \mathrm{C} \mathrm{ha}^{-1}$; $\mathrm{SOC}_{\text {horizon }}=$ SOC stock for a constituent soil horizon, $\mathrm{Mg} \mathrm{C} \mathrm{ha}^{-1}$; $[\mathrm{SOC}]=$ concentration of soil organic carbon, g C (kg soil $)^{-1}$; Bulk Density = soil mass per sample volume, $\mathrm{Mg} \mathrm{m}^{-3}$; Depth = horizon depth or thickness of soil layer, $\mathrm{m}$; frag $=\%$ volume of coarse fragments/100, dimensionless.

\subsection{Total Carbon Stock Change Estimation}

Biomass carbon stock density $\left(\mathrm{Mg} \mathrm{C} \mathrm{ha}^{-1}\right)$ for each of the land use was estimated by using the default carbon content of $47 \%$ [37]. Above ground biomass (AGB) carbon stock comprised the sum of above ground estimates of trees, saplings/shrubs/bamboos, herbs, litter and deadwood; while below ground biomass (BGB) carbon stock comprised the below ground estimates of trees, saplings/shrubs/bamboos and herbs. Total carbon stock of each land use types was estimated as the sum of stock in the different carbon pools: vegetation biomass (AGB and BGB) and SOC stock $(0-45 \mathrm{~cm})$. Carbon stock change $\left(\mathrm{Mg} \mathrm{C} \mathrm{ha}^{-1}\right)$ after land use change is estimated depending on the changes in carbon stocks 
between prior $\left(C_{L U O}\right)$ and immediate $\left(C_{L U n}\right)$ land use type [38]. The carbon stock of prior land use type was set as the baseline for calculating the rate of carbon stock change $\left(\mathrm{Mg} \mathrm{C} \mathrm{ha}{ }^{-1} \cdot \mathrm{yr}^{-1}\right)$ in the conversion process, and thus the rate of change $\left(R_{\text {stock }}\right)$ is calculated as follows:

$$
R_{\text {stock }}=\frac{C_{L U 0}-C_{L U n}}{\text { Age of } C_{L U n}}
$$

\subsection{Data Analysis}

Analysis of variance (ANOVA) was tested at $95 \%$ confidence interval to study the effect of major land use sectors and land use types on plant density, basal area cover, soil $\mathrm{BD}, \mathrm{SOC}$ concentration and carbon stock in various pools with general linear model (GLM) test. Tukey HSD (honestly significant difference) post hoc test was performed to indicate significant differences $(p<0.05)$ in carbon stock between the major land use sectors. All statistical calculations and figures were prepared using MS-Excel 2007 and IBM SPSS, ver.17.0.

\section{Results and Discussion}

\subsection{Land Use Characteristics}

Density and basal area of the trees and saplings/shrubs/bamboo showed significant variation $(\mathrm{p}<0.05)$ in different land use types (Table 2$)$. The highest tree density was encountered in arecanut plantation $\left(1520 \mathrm{ha}^{-1}\right)$ and the lowest in grassland $\left(110 \mathrm{ha}^{-1}\right)$. Saplings/shrubs/bamboo density was highest in bamboo forest $\left(26,833 \mathrm{ha}^{-1}\right)$ followed by dense forest $\left(7817 \mathrm{ha}^{-1}\right)$ and the lowest in oil palm plantation $\left(1150 \mathrm{ha}^{-1}\right)$. No trees and woody species were encountered in the Wet Rice Cultivation land use system. Plant density (individual ha ${ }^{-1}$ ) variation in different land use types was greatly influenced by the intensity of anthropogenic interventions and management practices [39]. The presence of more number of trees in jhum fallow as compared to current jhum in the present study indicated a rapid recovery and high resilience of regenerating secondary forest, however tree growth was reportedly inhibited by shrub dominance [40]. Tree densities in old and young homegarden (513 and $408 \mathrm{ha}^{-1}$ respectively) from the present study are higher in range with $239-319 \mathrm{ha}^{-1}$ in Kerala [41] and $220-409 \mathrm{ha}^{-1}$ in Philippines [42] which might be due to the maximum number of trees in lower girth classes $(<90 \mathrm{~cm} \mathrm{dbh})$ and multi-strata canopy structure as reported from homegardens in Mizoram [43]. Low tree density $\left(408 \mathrm{ha}^{-1}\right)$ observed in open forest is attributed to deforestation prevalent due to land use change conversions [44]. Low density of bamboo (Melocanna baccifera) in the present study with 26833 culms ha $^{-1}$ might be due to overexploitation of mature culms more than 4 years old leaving mostly the immature culms [45]. Amongst the forest, dense forest followed by open forest had showed significantly $(\mathrm{p}<$ 0.05 ) higher tree densities than bamboo forest and grassland. The basal area of trees was highest in oil palm plantation $\left(117.4 \mathrm{~m}^{2} \cdot \mathrm{ha}^{-1}\right)$ and the lowest in bamboo forest $\left(1.8 \mathrm{~m}^{2} \cdot \mathrm{ha}^{-1}\right)$. Dense forest observed the highest understorey woody 
Table 2. Density (individual ha $\left.{ }^{-1}\right)$ and Basal Area $\left(\mathrm{m}^{2} \cdot \mathrm{ha}^{-1}\right)$ of trees and saplings/shrubs/ bamboo in different land uses in Mizoram, Northeast India.

\begin{tabular}{|c|c|c|c|c|c|c|}
\hline \multirow{2}{*}{$\begin{array}{l}\text { Major Land } \\
\text { Use Sectors }\end{array}$} & \multirow{2}{*}{$\begin{array}{l}\text { Land use } \\
\text { Sub-types }\end{array}$} & \multirow{2}{*}{$\begin{array}{c}\text { Mean Age } \\
\text { (years) }\end{array}$} & \multicolumn{2}{|c|}{ Trees } & \multicolumn{2}{|c|}{ Saplings/Shrubs/Bamboo } \\
\hline & & & Density & Basal Area & Density & Basal Area \\
\hline \multirow{3}{*}{ Agriculture } & Current Jhum (3) & $1.7 \pm 0.11$ & $148 \pm 18$ & $3.9 \pm 0.5$ & $3700 \pm 406$ & $2.4 \pm 0.6$ \\
\hline & Jhum Fallow (3) & $7.7 \pm 0.4$ & $219 \pm 18$ & $5.3 \pm 0.6$ & $3183 \pm 219$ & $0.8 \pm 0.1$ \\
\hline & Wet Rice Cultivation (3) & $30.0 \pm 0.0$ & $0 \pm 0$ & $0.0 \pm 0.0$ & $0 \pm 0$ & $0.0 \pm 0.0$ \\
\hline \multirow{3}{*}{ Agroforestry } & Old Homegarden (3) & $17.3 \pm 0.4$ & $513 \pm 21$ & $14.9 \pm 1.1$ & $3700 \pm 268$ & $4.8 \pm 1.0$ \\
\hline & Young Homegarden (3) & $10.8 \pm 0.4$ & $408 \pm 13$ & $10.0 \pm 0.6$ & $3517 \pm 140$ & $3.2 \pm 0.2$ \\
\hline & Dense Forest (3) & $41.7 \pm 1.9$ & $982 \pm 37$ & $36.2 \pm 0.6$ & $7817 \pm 377$ & $16.0 \pm 0.9$ \\
\hline \multirow{3}{*}{ Forest } & Open Forest (3) & $41.7 \pm 1.9$ & $408 \pm 13$ & $19.8 \pm 2.7$ & $3433 \pm 282$ & $5.6 \pm 0.7$ \\
\hline & Bamboo Forest (3) & $14.7 \pm 0.4$ & $194 \pm 16$ & $1.8 \pm 0.2$ & $26833 \pm 662$ & $14.3 \pm 0.3$ \\
\hline & Grassland (3) & $23.7 \pm 1.3$ & $110 \pm 10$ & $3.1 \pm 0.4$ & $1883 \pm 131$ & $0.5 \pm 0.1$ \\
\hline \multirow{9}{*}{ Plantation } & Arecanut Plantation (2) & $16.5 \pm 0.6$ & $1520 \pm 56$ & $17.6 \pm 1.0$ & $1700 \pm 217$ & $0.4 \pm 0.1$ \\
\hline & Coffee Plantation (1) & $50.0 \pm 0.0$ & $236 \pm 8$ & $62.0 \pm 3.7$ & $3600 \pm 183$ & $9.2 \pm 0.6$ \\
\hline & Mango Plantation (1) & $15.0 \pm 0.0$ & $684 \pm 12$ & $24.7 \pm 0.9$ & $1450 \pm 126$ & $0.8 \pm 0.1$ \\
\hline & Oil palm Plantation (2) & $7.0 \pm 0.4$ & $154 \pm 4$ & $117.4 \pm 16.2$ & $1150 \pm 295$ & $0.4 \pm 0.1$ \\
\hline & Orange Plantation (2) & $10.5 \pm 1.7$ & $855 \pm 34$ & $7.7 \pm 1.7$ & $2750 \pm 330$ & $1.5 \pm 0.6$ \\
\hline & Pine Plantation (1) & $12.0 \pm 0.0$ & $331 \pm 41$ & $22.8 \pm 3.5$ & $1600 \pm 318$ & $1.7 \pm 0.2$ \\
\hline & Teak Plantation (2) & $14.0 \pm 0.8$ & $942 \pm 78$ & $40.1 \pm 6.4$ & $1875 \pm 426$ & $0.6 \pm 0.1$ \\
\hline & F-value & 165.44 & 207.38 & 41.21 & 387.34 & 94.44 \\
\hline & p-value & 0.000 & 0.000 & 0.000 & 0.000 & 0.000 \\
\hline
\end{tabular}

Note: Values are mean followed by standard errors with \pm . Results of one way ANOVA at $95 \%$ confidence level has been given in lower portion of the table. Figures within parenthesis are the number of permanent plots for each land use selected.

vegetation basal area with $16.0 \mathrm{~m}^{2} \cdot \mathrm{ha}^{-1}$ followed by bamboo forest $\left(14.3 \mathrm{~m}^{2} \cdot \mathrm{ha}^{-1}\right)$ and the lowest in arecanut and oil palm plantations $\left(0.4 \mathrm{~m}^{2} \cdot \mathrm{ha}^{-1}\right)$. Basal area cover in different land use is dependent on species composition, tree size and growth pattern [46]. Despite low tree density, oil palm had the highest basal area $\left(117.4 \mathrm{~m}^{2} \cdot \mathrm{ha}^{-1}\right)$ followed by coffee plantation comprising of matured trees $(62.0$ $\left.\mathrm{m}^{2} \cdot \mathrm{ha}^{-1}\right)$ as a result of maximum number of trees in large circumference class. Whereas, the basal area in orange $\left(7.7 \mathrm{~m}^{2} \cdot \mathrm{ha}^{-1}\right)$ and arecanut $\left(17.6 \mathrm{~m}^{2} \cdot \mathrm{ha}^{-1}\right)$ plantations were low due to maximum distribution of stems in small size circumference class. Overall, average tree density and basal area was the highest in plantations with $745 \mathrm{ha}^{-1}$ and $43.21 \mathrm{~m}^{2} \cdot \mathrm{ha}^{-1}$ respectively showing significant differences with the other land uses. However, the Tukey HSD test indicate no significant differences in tree basal area cover among agriculture, agroforestry and forest $(\mathrm{p}>0.05)$. Higher overall density and basal area in plantation compared to forest, agroforestry and agriculture indicate the efficiency of land use pattern where farmers follow intensive monoculture practices. However, land use conversion to plantation accompanies loss of biodiversity, vegetation structural 
changes, lower ground water table, etc. which further affects the ecosystem's carbon dynamics [47].

Soil bulk density $(\leq 2 \mathrm{~mm}$ ) and soil organic carbon (SOC) content also varied significantly $(\mathrm{p}<0.05)$ amongst different land use types at various soil depths (Table 3). Agroforestry based land uses showed higher bulk density in all depths amongst the major land use sectors, however significantly $(\mathrm{p}<0.05)$ different only in $0-15$ and $15-30 \mathrm{~cm}$. Soil bulk density was highest under old home garden $(0-15$ and $15-30 \mathrm{~cm})$ and wet rice cultivation $(30-45 \mathrm{~cm})$ and lowest at all depth classes in the pine plantations. The higher soil bulk density found in all soil layers in agroforestry and plantation compared to forest can be attributed to more soil compaction as a result of frequent cultivation activities; however, similar bulk density values in agriculture with forest might be due to constant tillage practices adopted [48]. SOC concentration (\%) decreased significantly $(\mathrm{p}<0.05)$ with increasing soil depth in all land uses. The decreasing trend of SOC content with increasing soil depth, common in all mineral soils, is in agreement with earlier studies [36] [49]. This might be due to higher organic matter input and

Table 3. Soil Bulk Density of fine soil $(<2 \mathrm{~mm})$ and Soil organic Carbon (SOC) concentration at various depth classes $(\mathrm{cm})$ in different land use systems in Mizoram, Northeast India.

\begin{tabular}{|c|c|c|c|c|c|c|}
\hline \multirow{2}{*}{$\begin{array}{l}\text { Land use } \\
\text { Sub-types }\end{array}$} & \multicolumn{3}{|c|}{ Bulk Density $\left(\mathrm{g} \cdot \mathrm{cm}^{-3}\right)$} & \multicolumn{3}{|c|}{ SOC (\%) } \\
\hline & $0-15$ & $15-30$ & $30-45$ & $0-15$ & $15-30$ & $30-45$ \\
\hline Current Jhum & $0.43 \pm 0.03$ & $0.41 \pm 0.03$ & $0.38 \pm 0.03$ & $2.51 \pm 0.35$ & $2.01 \pm 0.30$ & $1.35 \pm 0.13$ \\
\hline Jhum Fallow & $0.44 \pm 0.05$ & $0.42 \pm 0.05$ & $0.41 \pm 0.05$ & $2.12 \pm 0.34$ & $1.26 \pm 0.10$ & $0.83 \pm 0.15$ \\
\hline Wet Rice Cultivation & $0.60 \pm 0.01$ & $0.66 \pm 0.01$ & $0.71 \pm 0.03$ & $2.90 \pm 0.05$ & $1.28 \pm 0.06$ & $0.69 \pm 0.05$ \\
\hline Old Homegarden & $0.67 \pm 0.04$ & $0.68 \pm 0.03$ & $0.70 \pm 0.03$ & $2.44 \pm 0.12$ & $1.85 \pm 0.15$ & $1.66 \pm 0.06$ \\
\hline Young Homegarden & $0.65 \pm 0.01$ & $0.67 \pm 0.01$ & $0.67 \pm 0.02$ & $1.65 \pm 0.04$ & $1.68 \pm 0.07$ & $0.94 \pm 0.03$ \\
\hline Dense Forest & $0.40 \pm 0.03$ & $0.37 \pm 0.02$ & $0.38 \pm 0.03$ & $4.82 \pm 0.45$ & 3.72 & $2.13 \pm 0.21$ \\
\hline Open Forest & $0.50 \pm 0.04$ & $0.48 \pm 0.04$ & $0.50 \pm 0.04$ & $2.67 \pm 0.10$ & $1.67 \pm 0.07$ & $1.45 \pm 0.06$ \\
\hline Bamboo Forest & $0.62 \pm 0.01$ & $0.60 \pm 0.01$ & $0.60 \pm 0.01$ & $1.28 \pm 0.04$ & $1.10 \pm 0.04$ & $0.90 \pm 0.03$ \\
\hline Grassland & $0.47 \pm 0.04$ & $0.44 \pm$ & $0.43 \pm 0.05$ & $2.20 \pm 0.36$ & $1.19 \pm 0.12$ & $0.56 \pm$ \\
\hline Arecanut Plantation & $0.56 \pm 0.06$ & $0.58 \pm 0.07$ & $0.58 \pm 0.07$ & $2.10 \pm 0.11$ & $1.68 \pm 0.09$ & $1.35 \pm 0.07$ \\
\hline Coffee Plantation & $0.50 \pm 0.00$ & $0.51 \pm 0.00$ & $0.51 \pm 0.00$ & $2.01 \pm 0.05$ & $1.43 \pm 0.04$ & $0.97 \pm 0.03$ \\
\hline Mango Plantation & $0.52 \pm$ & $0.54 \pm$ & $0.56 \pm$ & $1.08 \pm$ & $0.53 \pm$ & 0.38 \\
\hline Oil palm Plantation & $0.60 \pm 0.02$ & $0.56 \pm$ & $0.64 \pm$ & $1.87 \pm$ & $1.15=$ & $0.96=$ \\
\hline Orange Plantation & $0.63 \pm 0.03$ & $0.66 \pm 0.04$ & $0.66 \pm 0.05$ & $1.76 \pm 0.07$ & $1.30 \pm 0.09$ & $0.95 \pm 0.07$ \\
\hline Pine Plantation & $0.26 \pm 0.00$ & $0.26 \pm 0.00$ & $0.26 \pm 0.00$ & $3.40 \pm 0.02$ & $1.95 \pm 0.06$ & $1.41 \pm 0.09$ \\
\hline Teak Plantation & $0.63 \pm 0.07$ & $0.65 \pm 0.08$ & $0.65 \pm 0.08$ & $2.11 \pm 0.12$ & $1.41 \pm 0.19$ & $0.90 \pm 0.03$ \\
\hline F-value & 8.13 & 9.92 & 10.01 & 12.37 & 13.88 & 18.59 \\
\hline p-value & 0.000 & 0.000 & 0.000 & 0.000 & 0.000 & 0.000 \\
\hline
\end{tabular}

Note: Values are mean followed by standard errors with \pm . Results of one way ANOVA at $95 \%$ confidence level has been given in lower portion of the table. 
more microbial activities in the upper soil layers by plant roots [50]. SOC content was highest in dense forest and lowest in mango plantation for all soil depth.SOC content was observed highest in forest with $2.74 \%$ and $1.92 \%$ for 0 15 and $15-30 \mathrm{~cm}$ soil depth respectively, showing significant $(\mathrm{p}<0.05)$ differences only with plantations.SOC content showed significant $(\mathrm{p}<0.05)$ differences only between agriculture and forest at $15-30 \mathrm{~cm}$ amongst the major land uses, highest being in agroforestry (1.30\%). Plantations had the lowest SOC content of $2.0 \%$ and $1.36 \%$ in $0-15$ and $15-30 \mathrm{~cm}$ soil depth respectively, while agriculture land use had the lowest SOC content $(0.95 \%)$ at $30-45 \mathrm{~cm}$ soil depth. Average SOC content was found highest in forest significantly $(\mathrm{p}<0.05)$ different from plantations only (Figure 3). Lower SOC content in plantation and agriculture as compared to forest and agroforestry could be due to less organic matter input and more soil disturbance resulting in high carbon mineralization rate as a result of cultivation [51] [52] [53]. Removal of biomass during harvesting and periodic tillage breaking up soil macro aggregates further reduces SOC content in agriculture and plantations [54].

The highest biomass (aboveground + belowground) was observed in coffee plantation (1065.44 $\mathrm{Mg} \mathrm{ha}^{-1}$ ) followed by teak plantation (487.03 $\mathrm{Mg} \mathrm{ha}^{-1}$ ), dense forest $\left(341.38 \mathrm{Mg} \mathrm{ha}^{-1}\right.$ ) and the lowest in wet rice cultivation $(7.63 \mathrm{Mg}$ $\left.\mathrm{ha}^{-1}\right)$. Amongst the forest, dense forest recorded the highest biomass with significant ( $\mathrm{p}<0.05)$ differences followed by open forest $\left(178.54 \mathrm{Mg} \mathrm{ha}^{-1}\right)$, bamboo forest (14.60 $\mathrm{Mg} \mathrm{ha}^{-1}$ ) and grassland (39.22 $\mathrm{Mg} \mathrm{ha}^{-1}$ ). The allometric models and sampling approach used could have substantial influences on the results of ground based biomass estimates, and thus locally developed and calibrated models have the potential to minimize this uncertainty in biomass carbon accounting [28] [55] [56]. However, in our present study, we used the most recent model keeping into account of similarities in climatic and ecological parameters.

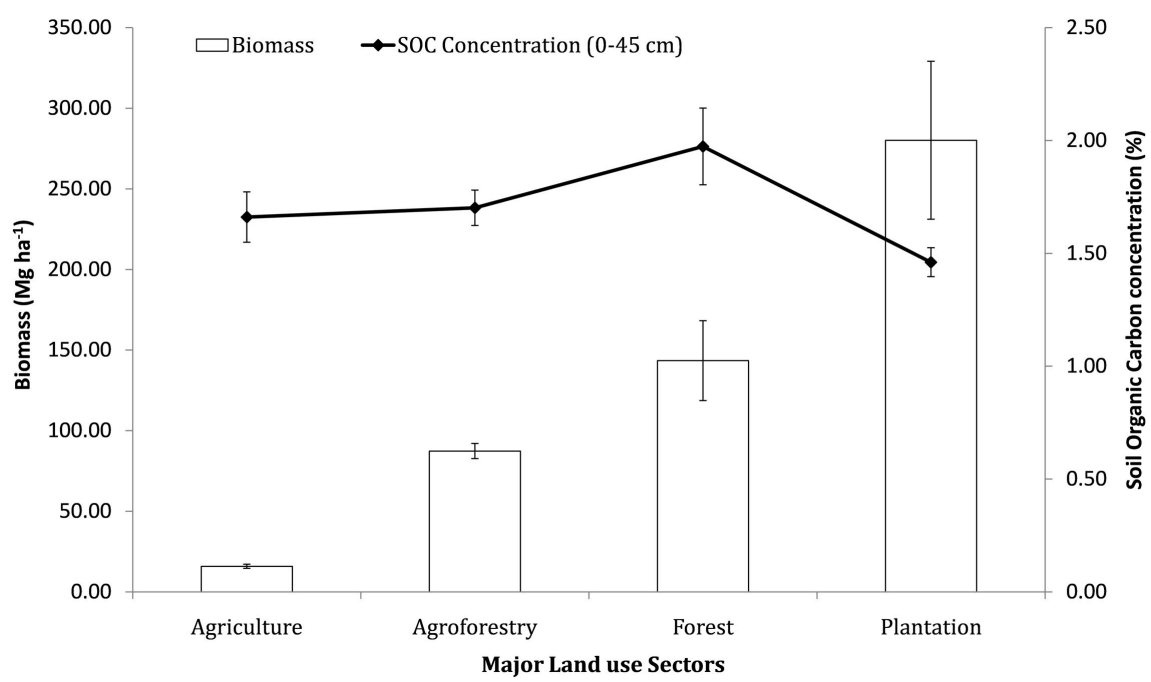

Figure 3. Biomass and Soil Organic Carbon concentration of major land use sectors in Mizoram, Northeast India. Different letters a, b, c, d indicate significant difference between the different major land use sectors. 
Amongst the plantations, orange and oil palm plantations recorded the lowest biomass (34.85 and $47.19 \mathrm{Mg} \mathrm{ha}^{-1}$ respectively). On an average, highest biomass was found in plantation (280.13 $\mathrm{Mg} \mathrm{ha}^{-1}$ ) and lowest in agriculture $(15.84 \mathrm{Mg}$ $\left.\mathrm{ha}^{-1}\right)$. Higher biomass in plantation, forest and agroforestry is mainly attributed by the presence of more woody vegetation in the form of trees and shrubs as compared to agriculture. Role of these tree-based systems in atmospheric carbon sequestration is well understood, especially in the tropics, however it depends on the structure and functions of the different components within the system affected by environmental and socio-economic factors [57] [58] [59].

\subsection{Vegetation Biomass Carbon, SOC and Total Ecosystem Carbon Stock}

Vegetation biomass carbon (VBC) stock comprising of all aboveground and belowground components of trees, saplings/shrubs/bamboos, herbs, standing litter and deadwood showed a significant $(\mathrm{p}<0.05)$ variation amongst the different land use types (Table 4). VBC stock was highest in coffee plantation (500.76 Mg $\mathrm{C} \mathrm{ha}^{-1}$ ) and lowest in wet rice cultivation $\left(3.59 \mathrm{Mg} \mathrm{C} \mathrm{ha}^{-1}\right)$. Highest VBCS in

Table 4. Carbon stock $\left(\mathrm{Mg} \mathrm{C} \mathrm{ha}^{-1}\right)$ distribution in different pools of various land use types in Mizoram, Northeast India.

\begin{tabular}{|c|c|c|c|c|}
\hline Land use Sub-types & VBC Stock & SOC Stock & TEC Stock & SOC: $\operatorname{TEC}(\%)$ \\
\hline Current Jhum & $10.32^{\text {abehij }}$ & $32.83^{\text {abceghijklmno }}$ & $43.15^{\text {abcdhijk }}$ & $75.47^{\text {abgm }}$ \\
\hline Jhum Fallow & $8.43^{\text {abehij }}$ & $22.92^{\text {abhiklmn }}$ & $31.35^{\text {abdhijk }}$ & $73.33^{\mathrm{abglm}}$ \\
\hline Wet Rice Cultivation & $3.59^{\text {abehij }}$ & $46.21^{\text {acdefghijkmno }}$ & $49.80^{\text {abcdhijk }}$ & $92.75^{\mathrm{cg}}$ \\
\hline Old Homegarden & $46.49^{\text {abdehij }}$ & $59.07^{\text {cdefgikno }}$ & $105.56^{\text {accdfhijk }}$ & $56.58^{\mathrm{dehlm}}$ \\
\hline Young Homegarden & $35.62^{\text {abdehij }}$ & $42.63^{\text {acdeghijklmno }}$ & $78.25^{\text {abdfhijk }}$ & $54.54^{\mathrm{dehl}}$ \\
\hline Dense Forest & $160.45^{\text {cfhk }}$ & $62.58^{\text {cdfjo }}$ & $223.03^{\text {eghl }}$ & $30.45^{\text {fino }}$ \\
\hline Open Forest & $83.92^{\text {bdhij }}$ & $42.90^{\text {acdeghijklmno }}$ & $126.82^{\text {cdfghijk }}$ & $35.67^{\text {fin }}$ \\
\hline Bamboo Forest & $6.86^{\text {abehij }}$ & $29.83^{\text {abceghijklmno }}$ & $36.69^{\text {abdhijk }}$ & $81.18^{\mathrm{abcgm}}$ \\
\hline Grassland & $18.43^{\text {abehij }}$ & $27.68^{\text {abceghijklmno }}$ & $46.11^{\mathrm{abcdhijk}}$ & $56.30^{\text {dehlm }}$ \\
\hline Arecanut Plantation & $138.62^{\text {cdfhj }}$ & $44.52^{\text {acdefghijklmno }}$ & $183.14^{\text {efghik }}$ & $23.65^{\text {fijkno }}$ \\
\hline Coffee Plantation & $500.76^{\mathrm{g}}$ & $33.38^{\text {abcdeghijklmno }}$ & $534.14^{\mathrm{h}}$ & $6.33^{\mathrm{ijko}}$ \\
\hline Mango Plantation & $81.45^{\text {abdefhij }}$ & $16.00^{\text {abeghijklmn }}$ & $97.45^{\text {abcdfghik }}$ & $16.57^{\mathrm{fijko}}$ \\
\hline Oil palm Plantation & $22.18^{\text {abdehij }}$ & $36.73^{\text {abceghijklmno }}$ & $58.90^{\mathrm{abcdfhijk}}$ & $60.51^{\mathrm{dhlm}}$ \\
\hline Orange Plantation & $16.38^{\text {abdehij }}$ & $39.49^{\text {abcdeghijklmn }}$ & $55.87^{\mathrm{abcdfhijk}}$ & $69.92^{\text {bdeghlm }}$ \\
\hline Pine Plantation & $62.39^{\text {abdefhij }}$ & $26.05^{\text {abceghijklmno }}$ & $88.44^{\text {abcdfghijk }}$ & $30.53^{\text {fikno }}$ \\
\hline Teak Plantation & $224.68^{\mathrm{ck}}$ & $44.66^{\text {acdefghijkmno }}$ & $269.33^{\text {cehl }}$ & $17.18^{\mathrm{ijkno}}$ \\
\hline F-value & 50.28 & 8.18 & 47.69 & 75.47 \\
\hline p-value & 0.000 & 0.000 & 0.000 & 0.000 \\
\hline
\end{tabular}

Note: Values are mean and results of one way ANOVA at 95\% confidence level has been given in lower portion of the table. Superscripted different letters indicate significant difference between the different land use types. VBC-Vegetation Biomass Carbon; SOC-Soil Organic Carbon; TEC-Total Ecosystem Carbon. 
coffee plantation (500.76 Mg C ha ${ }^{-1}$ ) was mainly contributed by the mature big trees (50 years old) present there as shade trees. Teak plantation, dense forest and arecanut plantations had a fairly higher biomass carbon storage than other land uses. The higher value of VBCS in current jhum in comparison to jhum fallows was attributed by the presence of more deadwood biomass in the former following its conversions from forest. Orange and oil palm plantations had lesser VBCS amongst plantations owing to its age and species composition, in accordance to low values $76.3 \mathrm{Mg} \mathrm{C} \mathrm{ha}^{-1}$ for a 25 year old orange plantation and 45.3 $\mathrm{Mg} \mathrm{C} \mathrm{ha}^{-1}$ for a 23 years old oil palm plantation reported from Ghana [60]. VBC stock was the highest in plantations (131.66 $\mathrm{Mg} \mathrm{C} \mathrm{ha}^{-1}$ ) and follows the trend: plantation $>$ forest $>$ agroforestry $>$ agriculture (Table 5). SOC stock was highest in agroforestry $\left(50.85 \mathrm{MgC} \mathrm{ha}^{-1}\right)$ and followed the trend: agroforestry $>$ forest $>$ plantation > agriculture (Table 5). Highest VBCS in plantations from other land uses signifies the great potential for biomass carbon sequestration through effective and proper management planning.

The SOC stock up to $45 \mathrm{~cm}$ depth ranges from 16.00 (mango plantation) to $62.58 \mathrm{Mg} \mathrm{C} \mathrm{ha} \mathrm{ha}^{-1}$ (dense forest) and the total ecosystem carbon (TEC) stock which is the sum of VBC and SOC stocks ranged from 31.35 (jhum fallow) to $534.14 \mathrm{Mg} \mathrm{C} \mathrm{ha}^{-1}$ (coffee plantation) (Table 4). Differences in total ecosystem carbon (TEC) stock amongst land uses have been attributed to differences in VBCS and SOCS. The distributions of SOC proportion at different depths varied significantly in the different land use types (Figure 4). Overall, an average of $46.58 \%, 31.33 \%$ and $22.09 \%$ of SOC stock were distributed within $0-15,15-30$ and $30-45 \mathrm{~cm}$ soil depths respectively in all the land use systems. Location, soil type, tree species and plantation management system influencing soil bulk density and SOC content might be responsible for SOC stock differences between

Table 5. Vegetation Biomass Carbon (VBC), Soil Organic Carbon (SOC) and Total Ecosystem Carbon (TEC) stock expressed in $\mathrm{Mg} \mathrm{C} \mathrm{ha}^{-1}$ of major land use sectors in Mizoram, Northeast India.

\begin{tabular}{|c|c|c|c|c|c|c|}
\hline \multirow{2}{*}{$\begin{array}{l}\text { Major Land } \\
\text { Use Sectors }\end{array}$} & \multicolumn{3}{|c|}{ VBC stock } & \multirow{2}{*}{$\begin{array}{l}\text { SOC } \\
\text { stock }\end{array}$} & \multirow{2}{*}{ TEC stock } & \multirow{2}{*}{$\begin{array}{c}\text { SOC: } \\
\text { TEC (\%) }\end{array}$} \\
\hline & AGB & BGB & Total & & & \\
\hline Agriculture & $\begin{array}{l}5.87^{\mathrm{ab}} \\
(0.50)\end{array}$ & $\begin{array}{l}1.57^{\mathrm{ab}} \\
(0.15)\end{array}$ & $\begin{array}{l}7.44^{\mathrm{ab}} \\
(0.62)\end{array}$ & $\begin{array}{c}33.99^{\mathrm{acd}} \\
(1.85)\end{array}$ & $\begin{array}{l}41.43^{\mathrm{ab}} \\
(1.55)\end{array}$ & $\begin{array}{l}80.52^{\mathrm{a}} \\
(1.76)\end{array}$ \\
\hline Agroforestry & $\begin{array}{c}31.24^{\mathrm{abc}} \\
(1.69)\end{array}$ & $\begin{array}{l}9.82^{\mathrm{abc}} \\
(0.59)\end{array}$ & $\begin{array}{c}41.06^{\mathrm{abc}} \\
(2.22)\end{array}$ & $\begin{array}{c}50.85^{\mathrm{bc}} \\
(2.05)\end{array}$ & $\begin{array}{c}91.91^{\mathrm{abc}} \\
(3.70)\end{array}$ & $\begin{array}{c}55.56^{b c} \\
(1.21)\end{array}$ \\
\hline Forest & $\begin{array}{c}50.94^{\mathrm{bc}} \\
(8.79)\end{array}$ & $\begin{array}{l}16.47^{\mathrm{bc}} \\
(2.85)\end{array}$ & $\begin{array}{l}67.41^{\mathrm{bc}} \\
(11.63)\end{array}$ & $\begin{array}{c}40.75^{\text {abcd }} \\
(3.29)\end{array}$ & $\begin{array}{c}108.16^{b c} \\
(13.03)\end{array}$ & $\begin{array}{c}50.90^{b c} \\
(3.35)\end{array}$ \\
\hline Plantation & $\begin{array}{l}98.45^{\mathrm{d}} \\
(17.26)\end{array}$ & $\begin{array}{l}33.21^{\mathrm{d}} \\
(5.32)\end{array}$ & $\begin{array}{c}131.66^{\mathrm{d}} \\
(0.46)\end{array}$ & $\begin{array}{c}36.93^{\mathrm{abcd}} \\
(22.56)\end{array}$ & $\begin{array}{l}168.59^{\mathrm{d}} \\
(23.25)\end{array}$ & $\begin{array}{l}36.00^{\mathrm{d}} \\
(3.70)\end{array}$ \\
\hline F-value & 12.12 & 14.63 & 14.63 & 5.37 & 11.40 & 35.33 \\
\hline $\mathrm{p}$-value & 0.000 & 0.000 & 0.000 & 0.000 & 0.000 & 0.000 \\
\hline
\end{tabular}

Note: Values are mean followed by standard errors within parenthesis. Results of one way ANOVA at 95\% confidence level has been given in lower portion of the table. Superscripted different letters indicate significant difference between the different major land use sectors. 


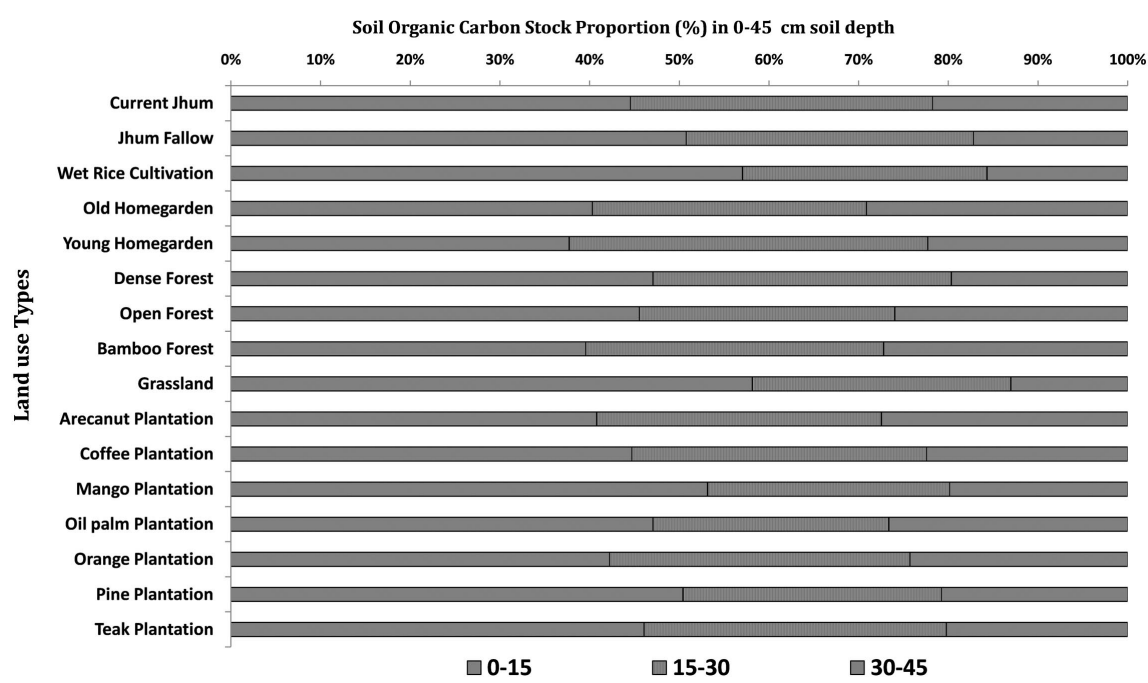

Figure 4. Soil organic carbon stock proportion at different depths across various land use types in Mizoram, Northeast India.

land uses and all the three soil depths [61] [62]. SOC stocks in grassland are low in comparison to other forest land use types, as reported from other parts of India [63]. In the present study, on an average more than one-third (46.58\%) of SOC was stored in the top $15 \mathrm{~cm}$ depth relative to the total depth studied (0 - 45 $\mathrm{cm})$, being the highest in grassland (58.14\%) followed by wet rice cultivation (57.05\%) in accordance to SOC vertical distribution pattern reported from other studies across the world [64] [65]. SOC stocks distribution at various soil depths except 0 - $15 \mathrm{~cm}$ across land use sectors indicated a significant decrease with increasing depth (Figure 5). Understanding the SOC vertical pattern of different land uses will enhance our knowledge of carbon dynamics along a profile and its potential response to climate change [66]. SOC stock in agroforestry was significantly $(\mathrm{p}<0.05)$ different only with agriculture and plantation. Agroforestry stored the highest SOC (50.85 Mg C ha ${ }^{-1}$ ) stock compared to forest and plantations and the lowest in agriculture for a soil depth of $0-45 \mathrm{~cm}$, which is comparable to findings from other studies where traditionally managed agroforestry systems have higher SOC storage than agricultural systems [17] [67] which may be due to differences in species diversity, composition and intensity of management practices leading to soil disruptions [68].

The SOC: TEC stock ratio was highest for wet rice cultivation $(92.75 \%)$ and the lowest was for mango plantation (16.57\%) across the land use types (Table 4). SOC: TEC was the highest for agriculture (80.52\%) followed by agroforestry $(55.56 \%)$, and lowest in plantation $(36.00 \%)$ being significantly $(\mathrm{p}<0.05)$ different from other major land uses (Table 5) which indicates the direction of change in carbon storage in different pools. In the present study, the higher proportion of SOC with corresponding low floor biomass and vegetative cover makes the land use more prone to SOC losses through accelerated soil erosion [69]. Low proportion of SOC in plantations may be due to constant removal of litter biomass through weeding, cleaning and harvesting. The ratio of SOC: TEC 


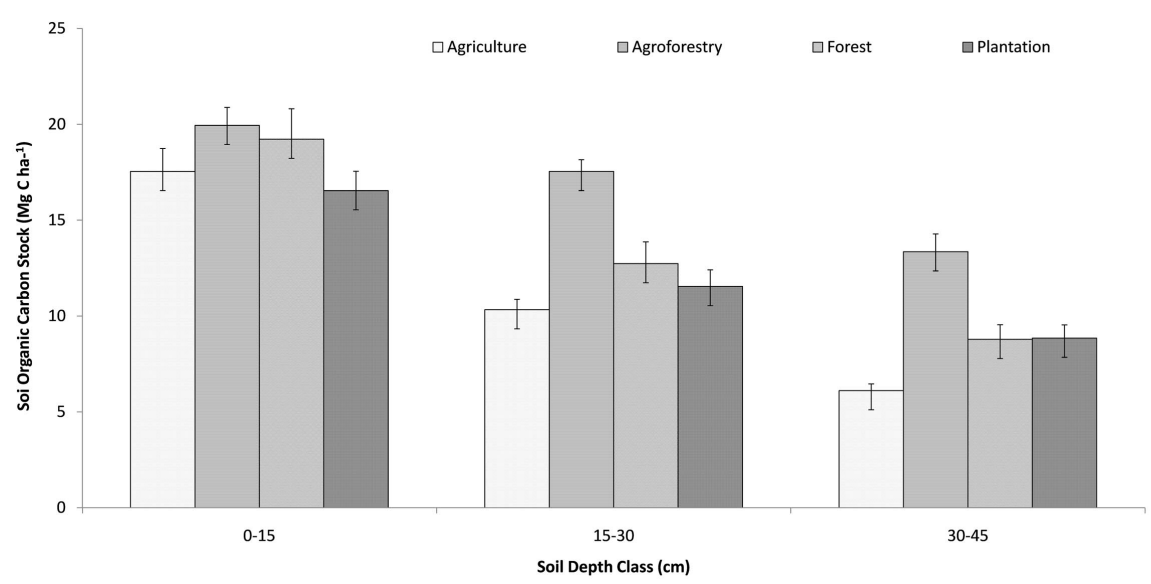

Figure 5. Variation of Soil Organic Carbon stock $\left(\mathrm{Mg} \mathrm{C} \mathrm{ha}^{-1}\right)$ across major land use sectors in various soil depths of Mizoram, Northeast India. Different letters indicate significant differences with respect to land use and depth at $\mathrm{p} \leq 0.05$. Letters $\mathrm{a}, \mathrm{b}, \mathrm{c}$ indicate the variation within land uses in different depth, while letters $\mathrm{x}, \mathrm{y}, \mathrm{z}$ indicate variation among the land uses in each depth.

implies the need for management practices to maintain the balance between plant biomass productivity and microbial decomposition for SOC stock following land use changes in the wake of impending climate change [70]. It is important to evaluate SOC storage potential and improve the biological cycle of ecosystems to maintain an equilibrium fixation and storage [71].

\subsection{Carbon Stock Change Estimation}

Land use changes showed positive and negative carbon stock change rates depending on land use type (Table 6). Positive rate of carbon stock change was observed in all the pools when current jhum was converted to teak, arecanut, young home garden and oil palm plantations. However, the conversion of current jhum to grassland witnessed a loss of SOC stocks $\left(-0.22 \mathrm{Mg} \mathrm{C} \mathrm{ha}^{-1} \cdot \mathrm{yr}^{-1}\right)$ although the vegetation biomass carbon stock gained $\left(0.34 \mathrm{Mg} \mathrm{C} \mathrm{ha}{ }^{-1} \cdot \mathrm{yr}^{-1}\right)$. Land use conversions may result either a decrease [72] or an increase in rate of SOCS change [73]. The negative rate of change following conversions of dense and open forest to current jhum and grasslands observed in the present study is similar to reports from China [74]. The establishment of arecanut and oil palm plantations from jhum fallows and grassland had also indicated a gain in carbon stock change rate of all pools. Establishment of oil palm plantations from old home garden and open forest also observed negative TECS change rate at -6.67 and $-9.70 \mathrm{MgC} \mathrm{ha}^{-1} \cdot \mathrm{yr}^{-1}$ respectively. The conversion of open forest and old homegarden to oil palm plantations also contributed carbon stock losses in all pools with TECS change rate of -6.67 and $-9.70 \mathrm{Mg} \mathrm{C} \mathrm{ha}^{-1} \cdot \mathrm{yr}^{-1}$ respectively. The rate of carbon stock change after conversion of different land use types to one or the other showed a wide range of variation (Figure 6). The highest positive TECS change rate was observed in teak plantations (10.86 Mg C ha- $\left.\mathrm{yr}^{-1}\right)$ and the least negative TECS change rate in current jhum $\left(-53.50 \mathrm{Mg} \mathrm{C} \mathrm{ha}{ }^{-1} \cdot \mathrm{yr}^{-1}\right)$. 
Table 6. Changes in Soil Organic Carbon (SOCS), Vegetation Biomass Carbon (VBCS) and Total Ecosystem Carbon (TECS) stock expressed in $\mathrm{Mg} \mathrm{C} \mathrm{ha}^{-1} \cdot \mathrm{yr}^{-1}$ after conversion of some important land use types in Mizoram, Northeast India.

\begin{tabular}{|c|c|c|c|c|c|c|c|c|}
\hline \multirow{2}{*}{$\begin{array}{c}\text { Land Use } \\
\text { Changes Type }\end{array}$} & \multicolumn{4}{|c|}{ SOCS Changes } & \multicolumn{3}{|c|}{ VBCS Changes } & \multirow{2}{*}{$\begin{array}{c}\text { TECS } \\
\text { Changes }\end{array}$} \\
\hline & $\begin{array}{l}0-15 \\
(\mathrm{~cm})\end{array}$ & $\begin{array}{c}15-30 \\
(\mathrm{~cm})\end{array}$ & $\begin{array}{c}30-45 \\
(\mathrm{~cm})\end{array}$ & $\begin{array}{c}0-45 \\
(\mathrm{~cm})\end{array}$ & $\begin{array}{l}\text { Above } \\
\text { ground }\end{array}$ & $\begin{array}{l}\text { Below } \\
\text { ground }\end{array}$ & Total & \\
\hline CJ to Teak & 0.42 & 0.29 & 0.13 & 0.84 & 11.32 & 3.99 & 15.31 & 16.16 \\
\hline JF to Arecanut & 0.40 & 0.41 & 0.50 & 1.31 & 5.67 & 2.22 & 7.89 & 9.20 \\
\hline CJ to Arecanut & 0.21 & 0.19 & 0.31 & 0.71 & 5.57 & 2.21 & 7.78 & 8.48 \\
\hline GL to Arecanut & 0.13 & 0.37 & 0.52 & 1.02 & 5.19 & 2.09 & 7.28 & 8.30 \\
\hline OF to Coffee & -0.09 & -0.03 & -0.07 & -0.19 & 6.45 & 1.89 & 8.34 & 8.15 \\
\hline OHG to Arecanut & -0.34 & -0.24 & -0.30 & -0.88 & 3.91 & 1.67 & 5.58 & 4.70 \\
\hline JF to DF & 0.43 & 0.32 & 0.20 & 0.95 & 2.74 & 0.91 & 3.65 & 4.60 \\
\hline $\mathrm{BF}$ to $\mathrm{DF}$ & 0.42 & 0.26 & 0.10 & 0.79 & 2.77 & 0.92 & 3.69 & 4.47 \\
\hline JF to YHG & 0.42 & 0.91 & 0.52 & 1.85 & 1.93 & 0.62 & 2.55 & 4.40 \\
\hline $\mathrm{CJ}$ to $\mathrm{DF}$ & 0.36 & 0.23 & 0.12 & 0.71 & 2.70 & 0.90 & 3.60 & 4.32 \\
\hline JF to Oil Palm & 0.81 & 0.33 & 0.83 & 1.97 & 1.47 & 0.50 & 1.96 & 3.94 \\
\hline $\mathrm{CJ}$ to $\mathrm{YHG}$ & 0.14 & 0.56 & 0.22 & 0.92 & 1.76 & 0.61 & 2.37 & 3.29 \\
\hline CJ to Oil Palm & 0.38 & -0.20 & 0.38 & 0.56 & 1.22 & 0.47 & 1.69 & 2.25 \\
\hline GL to Oil Palm & 0.17 & 0.24 & 0.88 & 1.29 & 0.33 & 0.21 & 0.54 & 1.83 \\
\hline YHG to OHG & 0.45 & 0.06 & 0.44 & 0.95 & 0.49 & 0.14 & 0.63 & 1.58 \\
\hline CJ to GL & 0.06 & -0.13 & -0.15 & -0.22 & 0.26 & 0.08 & 0.34 & 0.13 \\
\hline DF to $\mathrm{OF}$ & -0.24 & -0.21 & -0.03 & -0.47 & -1.37 & -0.47 & -1.84 & -2.31 \\
\hline OF to Pine & -0.53 & -0.39 & -0.48 & -1.4 & -1.35 & -0.44 & -1.79 & -3.20 \\
\hline OF to GL & -0.15 & -0.18 & -0.32 & -0.64 & -2.07 & -0.69 & -2.77 & -3.41 \\
\hline OHG to Orange & -0.68 & -0.46 & -0.73 & -1.87 & -2.26 & -0.61 & -2.87 & -4.73 \\
\hline DF to WRC & -0.10 & -0.27 & -0.17 & -0.55 & -5.23 & -3.92 & -1.31 & -5.77 \\
\hline OHG to Oil Palm & -0.93 & -1.20 & -1.06 & -3.19 & -2.68 & -0.79 & -3.47 & -6.67 \\
\hline DF to GL & -0.56 & -0.54 & -0.37 & -1.47 & -4.49 & -1.51 & -6.00 & -7.48 \\
\hline OF to Oil Palm & -0.32 & -0.37 & -0.19 & -0.88 & -6.68 & -2.14 & -8.82 & -9.70 \\
\hline OF to CJ & -2.95 & -0.70 & -2.39 & -6.04 & -33.17 & -10.99 & -44.16 & -50.20 \\
\hline DF to $\mathrm{CJ}$ & -8.90 & -5.86 & -3.09 & -17.85 & -90.08 & -67.46 & -22.62 & -107.93 \\
\hline
\end{tabular}

CJ-Current Jhum; JF-Jhum Fallow; WRC-Wet Rice cultivation; YHG-Young Homegarden; OHG-Old Homegarden; DF-Dense Forest; OF-Open Forest; BF-Bamboo Forest; GL-Grassland 


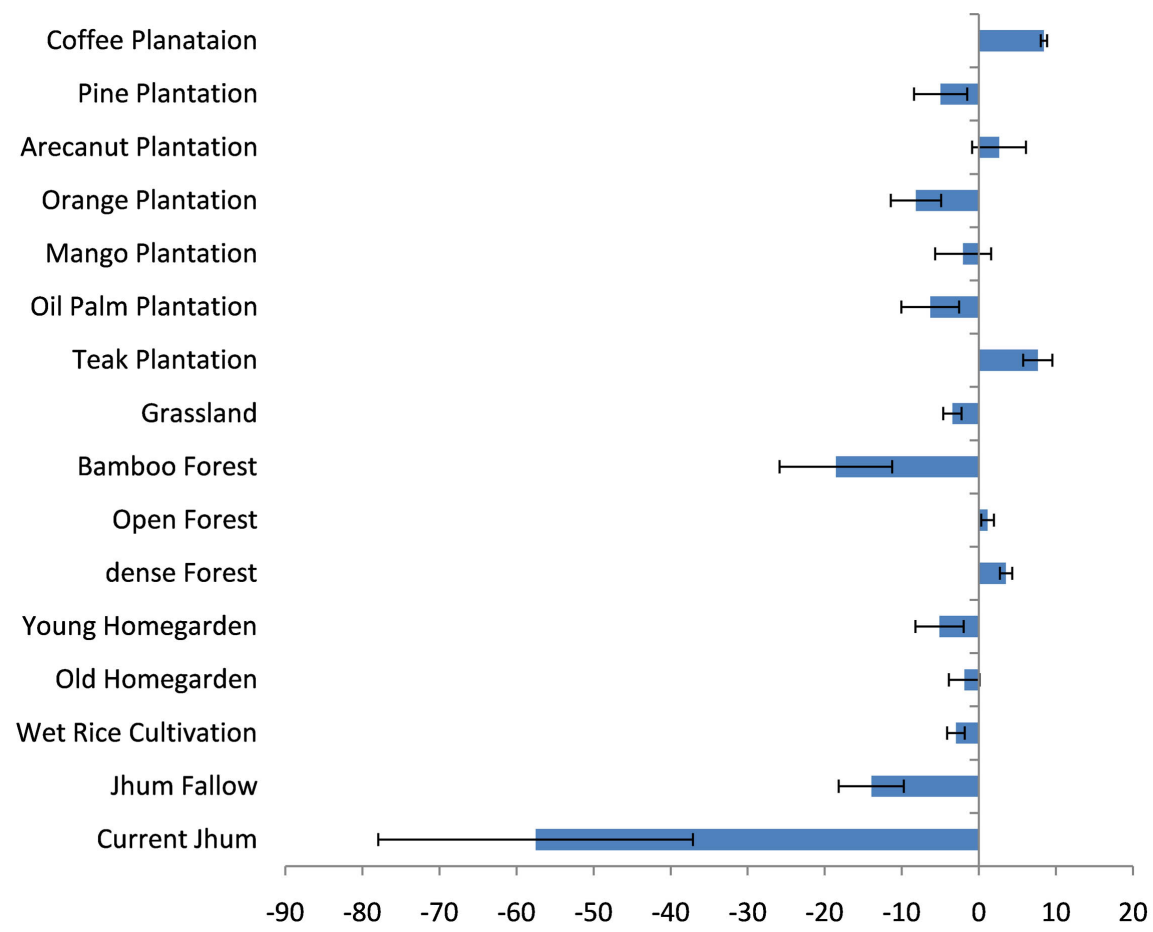

Figure 6. Average Total Ecosystem Carbon Stock change $\left(\mathrm{Mg} \mathrm{C} \mathrm{ha}^{-1} \cdot \mathrm{yr}^{-1}\right)$ after conversion in different land use types of Mizoram, Northeast India. Different letters indicate significant difference between the different land use types.

The highest TECS rate was computed at $6.61 \mathrm{Mg} \mathrm{C} \mathrm{ha}{ }^{-1} \cdot \mathrm{yr}^{-1}$ when agriculture was converted to plantation, and the least was observed when plantation converted to agriculture with $-36.27 \mathrm{Mg} \mathrm{Cha}^{-1} \cdot \mathrm{yr}^{-1}$. Conversion of jhum fallow and bamboo forest to dense forest also showed positive carbon stock change rates. Conversion of land uses to agriculture showed a negative TECS change rate of $-22.04 \mathrm{Mg} \mathrm{C} \mathrm{ha}{ }^{-1} \cdot \mathrm{yr}^{-1}$, while land use conversion to plantation attracts a positive TECS change rate of $3.59 \mathrm{Mg} \mathrm{C} \mathrm{ha}{ }^{-1} \cdot \mathrm{yr}^{-1}$ (Figure 7). Highest positive TECS change rate was observed when agriculture was converted to plantations (6.61 $\mathrm{Mg} \mathrm{C} \mathrm{ha} a^{-1} \cdot \mathrm{yr}^{-1}$ ) followed by agroforestry (3.58 $\left.\mathrm{Mg} \mathrm{C} \mathrm{ha}^{-1} \cdot \mathrm{yr}^{-1}\right)$ and forest (1.57 $\mathrm{Mg} \mathrm{C} \mathrm{ha} \mathrm{h}^{-1} \cdot \mathrm{yr}^{-1}$ ), while negative values were observed following conversion of land uses to agriculture. The conversions of current jhum, jhum fallow and grassland to arecanut and oil palm plantation crops had observed a positive SOCS change rate as reported from other similar studies [75] [76]. SOCS change rate showed a negative value with major land use conversions to agriculture; agroforestry and forest to plantation; and agroforestry to forest (Table 7). Whereas, SOCS change rate were positive in conversion of land uses to agroforestry; agriculture and plantation to forest; and agriculture to plantation. A positive SOCS change rate of $0.33 \mathrm{Mg} \mathrm{Cha} \mathrm{har}^{-1} \cdot \mathrm{yr}^{-1}$ in the top $20 \mathrm{~cm}$ soil was reported following conversion of cropland to forest in China which is similar to the findings from the present study [77]. The establishment of current jhum and grassland from dense and open had resulted manifold losses in SOCS, however the rate of change was comparatively lower in grassland similar with findings reported 


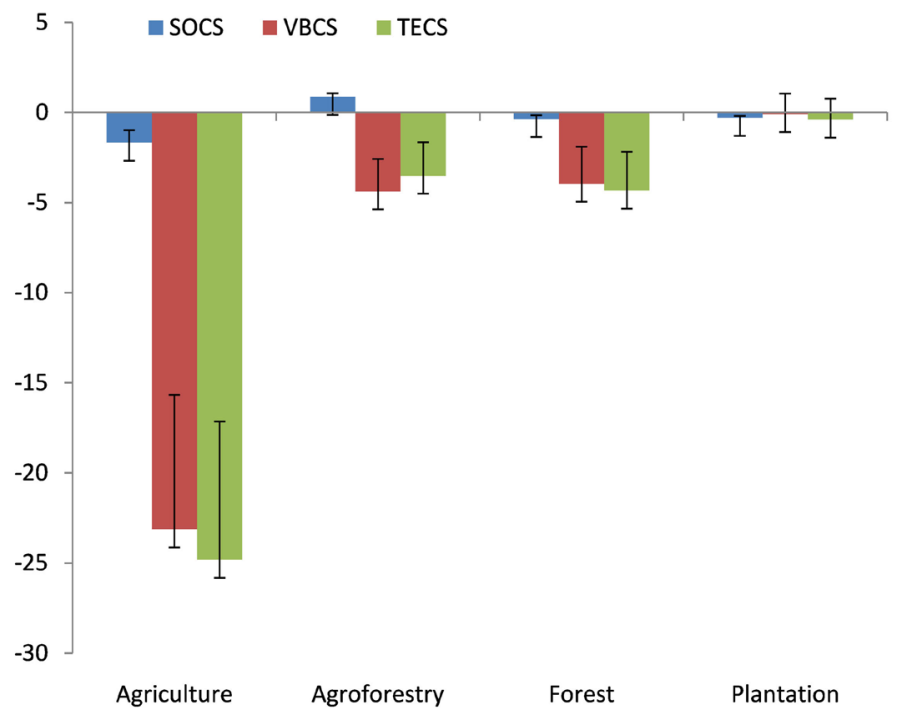

Figure 7. Average carbon stock change rate $\left(\mathrm{Mg} \mathrm{C} \mathrm{ha}^{-1} \cdot \mathrm{yr}^{-1}\right)$ after conversion in different major land use sectors of Mizoram, Northeast India. Different letters indicate significant difference between carbon pools among the land use. SOCS-Soil organic carbon stock; VBCS-Vegetation biomass carbon stock; TECS-total ecosystem carbon stock.

Table 7. Averaged changes in Soil Organic Carbon (SOCS), Vegetation Biomass Carbon (VBCS) and Total Ecosystem Carbon (TECS) stock expressed in $\mathrm{Mg} \mathrm{C} \mathrm{ha}{ }^{-1} \cdot \mathrm{yr}^{-1}$ after conversion of major land use sectors in Mizoram, Northeast India.

\begin{tabular}{cccc}
\hline Major Land Use Sector Changes & SOCS Changes & VBCS Changes & TECS Changes \\
\hline Agriculture to Plantation & $0.06 \pm 0.24^{\mathrm{abdef}}$ & $6.54 \pm 1.04^{\mathrm{ab}}$ & $6.61 \pm 1.10^{\mathrm{ab}}$ \\
Agroforestry to Plantation & $-1.24 \pm 0.30^{\mathrm{abcdef}}$ & $3.95 \pm 1.51^{\mathrm{ab}}$ & $2.71 \pm 1.70^{\mathrm{ab}}$ \\
Agriculture to Forest & $0.09 \pm 0.17^{\mathrm{abdef}}$ & $1.48 \pm 0.44^{\mathrm{ab}}$ & $1.57 \pm 0.56^{\mathrm{ab}}$ \\
Forest to Plantation & $-0.46 \pm 0.26^{\mathrm{abdef}}$ & $1.92 \pm 1.54^{\mathrm{ab}}$ & $1.46 \pm 1.74^{\mathrm{ab}}$ \\
Agriculture to Agroforestry & $1.13 \pm 0.36^{\mathrm{abdef}}$ & $2.45 \pm 0.13^{\mathrm{abc}}$ & $3.58 \pm 0.27^{\mathrm{abc}}$ \\
Agroforestry to Forest & $-0.58 \pm 0.29^{\mathrm{abdef}}$ & $0.15 \pm 0.75^{\mathrm{ab}}$ & $-0.43 \pm 1.02^{\mathrm{abc}}$ \\
Forest to Agroforestry & $0.62 \pm 0.44^{\mathrm{abdef}}$ & $-2.09 \pm 1.83^{\mathrm{abc}}$ & $-1.48 \pm 2.26^{\mathrm{abc}}$ \\
Plantation to Forest & $0.07 \pm 0.11^{\mathrm{abdef}}$ & $-4.14 \pm 1.52^{\mathrm{ab}}$ & $-4.07 \pm 1.57^{\mathrm{ab}}$ \\
Plantation to Agroforestry & $1.10 \pm 0.23^{\mathrm{abdef}}$ & $-8.31 \pm 3.48^{\mathrm{abc}}$ & $-7.21 \pm 3.53^{\mathrm{abc}}$ \\
Agroforestry to Agriculture & $-4.87 \pm 2.37^{\mathrm{acd}}$ & $-7.98 \pm 3.46^{\mathrm{abc}}$ & $-12.85 \pm 5.75^{\mathrm{abc}}$ \\
Forest to Agriculture & $-2.30 \pm 1.61^{\mathrm{abdf}}$ & $-14.69 \pm 7.80^{\mathrm{abc}}$ & $-16.99 \pm 9.35^{\mathrm{abc}}$ \\
Plantation to Agriculture & $-0.68 \pm 0.78^{\mathrm{abef}}$ & $-35.59 \pm 14.72^{\mathrm{bc}}$ & $-36.27 \pm 14.86^{\mathrm{bc}}$ \\
F-value & 4.05 & 3.89 & 3.83 \\
p-value & 0.000 & 0.000 & 0.000 \\
\hline
\end{tabular}

Note: Values are mean followed by standard errors with \pm . Results of one way ANOVA at $95 \%$ confidence level has been given in lower portion of the table. Superscripted different letters indicate significant difference between the different major land use sectors.

from tropical forest soils [78]. This implies the degradation impacts of slash and burn practices involved with shifting cultivation (jhum) in the tropics where 
land become scarce and leads to reduced fallow periods [79], thereby the natural nutrients recovery for crop production is not complete and the intensification of shifting cultivation on the same land makes it become unsustainable. In the present study, establishment of plantations following conversions from forest and homegardens observed a negative SOCS change rate similar to findings reported by other studies [80]. SOCS changes due to land use change are caused by changes in soil carbon inputs (litter quality and quantity) and outputs (alterations in decomposition processes) when one vegetation is replaced by the other [81]. VBCS change rate showed positive gain following conversion of land uses to plantation; agriculture and agroforestry to forest; and agriculture to agroforestry. Conversion of land uses to agriculture; forest and plantations to agroforestry; and forest to agroforestry had exhibited a negative VBCS change rate. This suggests that the tree-based systems have substantially enhanced the ecosystem carbon storage and aid to climate change mitigation/adaptation. In the present study, the absolute carbon stock change rates following land use change were higher in VBCS than SOCS, except for land use conversion from agroforestry to forest. This signifies the importance and vulnerability of vegetation biomass pool whose sequestration is greatly affected by land use management implications subject to changing climate and soil conditions. Therefore, land uses which are degraded physically, chemically and biologically following conversions need to be restored through tree-based systems. The study results indicate ecosystem carbon sequestration rates to be significantly high in plantations, however they have been often associated with environmental issues of biodiversity losses and disruption of ecological cycle [82]. Thus, the land use change management needs to focus and identify potential systems such as agroforestry systems which would preserve species, accumulate soil carbon and tree biomass in the longer run.

\section{Conclusion}

Diversified land use patterns in different sectors: agriculture, agroforestry, forest and plantations have been prevalent in Mizoram, Northeast India which is influenced by a combination of different reasons such as resource scarcity, market opportunities, policy interventions, increased vulnerability to resource access and change in attitudes. These land use changes in various forms affect the total ecosystem carbon storage whereby management practices involved induced great differences amongst carbon pools. The highest carbon stock was observed in plantations and the lowest in agriculture. Both biomass and soil carbon stocks were observed higher in tree-based land use systems compared to agriculture. The SOC stock proportionately contributed more in agriculture systems and less in plantations. Among all the managed plantations, coffee plantations have a dense canopy with large diameter shade trees and exhibited the highest carbon storage indicating the best management practices adopted. Absolute carbon stock change rate following conversions were maximum in agriculture with losses in all carbon pools. Conversions to agroforestry attract a positive change soil carbon pool; whereas conversions to plantations exhibited negative change 
in soil and a positive rate of change in biomass carbon with an overall gain in total ecosystem carbon stock. However, considering environmental management and conservation issues, the rampant conversion of land uses to plantation should not be encouraged. In all the land use changes, the rate of change is comparatively higher in biomass than soil carbon pools, which signifies that maximum gain/loss in total ecosystem carbon stock, can be achieved through the management perspectives to maintain vegetation type and cover in the system. Increase in vegetation and floor biomass will also eventually lead to soil carbon enrichment. Open forest and jhum fallows should be kept undisturbed and allowed to recover fully through natural and assisted regeneration to dense forest. Selective land use and adoption of scientific cultivation practices should be the efforts of policy makers in tune with climate and carbon mitigation challenges. Thus, agroforestry systems and plantations equipped with sustainable management practices could be adopted in large scale for restoration of degraded lands in Mizoram.

\section{Acknowledgements}

The authors thank all the farmers and villagers of different selected land use types in Mizoram for their help and co-operation during the field work. This work was supported by Department of Science and Technology, Government of India under the Grant No. DST/IS-STAC/CO ${ }_{2}$-SR-227/14(G)-AICP-AFOLU-IV.

\section{Conflicts of Interest}

No potential interest of conflict was reported by the authors.

\section{References}

[1] Dale, V.H. (1997) The Relationship between Land-Use Change and Climate Change. Ecological Applications, 7, 753-769. https://doi.org/10.1890/1051-0761(1997)007[0753:TRBLUC]2.0.CO;2

[2] Watson, T.R., Noble, I., Bolin, B., Ravindranath, N.H., Verardo, J.D. and Dokken, J. (2000) Land Use, Land-Use Change and Forestry. Cambridge University Press, Cambridge.

[3] Houghton, R.A. (2003) Revised Estimates of the Annual Net Flux of Carbon to the Atmosphere from Changes in Land Use and Land Management 1850-2000. Tellus, 55B, 378-390.

[4] Houghton, R.A., House, J.I., Pongratz, J., Van Der Werf, G.R., DeFries, R.S., Hansen, M.C., et al. (2012) Carbon Emission from Land Use and Land Cover Change. Biogeosciences, 9, 5125-5142. https://doi.org/10.5194/bg-9-5125-2012

[5] Muller, C., Eickhout, B., Zaehle, S., Bondeau, A., Cramer, W. and Lucht, W. (2007) Effects of Changes in $\mathrm{CO}_{2}$, Climate, and Land Use on the Carbon Balance of the Land Biosphere during the 21st Century. Journal of Geophysical Research, 122, G02032. https://doi.org/10.1029/2006JG000388

[6] Smith, P., Fang, C., Dawson, J.J.C. and Moncrieff, J.B. (2008) Impact of Global Warming on Soil Organic Carbon. Advances in Agronomy, 97, 1-43. https://doi.org/10.1016/S0065-2113(07)00001-6

[7] Zomer, R.J., Trabucco, A., Bossio, D.A. and Vercot, L.V. (2008) Climate Change 
Mitigation: A Spatial Analysis of Global Land Suitability for Clean Development Mechanism Afforestation and Reforestation. Agriculture, Ecosystems and Environment, 126, 67-80. https://doi.org/10.1016/j.agee.2008.01.014

[8] Saatchi, S.S., Harris, N.L., Brown, S., Lefsky, M., Mitchard, E.T.A., Salas, W., et al. (2011) Benchmark Map of Forest Carbon Stocks in Tropical Regions across Three Continents. Proceedings of the National Academy of Sciences, 108, 9899-9904. https://doi.org/10.1073/pnas.1019576108

[9] Rai, S.C. and Sharma, P. (2003) Carbon Sequestration with Forestry and Land Use/Cover Change: An Overview. Indian Forester, 129, 776-786.

[10] Lal, R. (2008) Sequestration of Atmospheric $\mathrm{CO}_{2}$ in Global Carbon Pools. Energy and Environmental Science, 1, 86-100. https://doi.org/10.1039/b809492f

[11] Zhang, M., Huang, X., Chuai, X., Yang, H., Lai, L. and Tan, J. (2005) Impact of Land Use Type Conversion on Carbon Storage in Terrestrial Ecosystems of China: A Spatial-Temporal Perspective. Scientific Report, 5, 10233. https://doi.org/10.1038/srep10233

[12] Ogle, S.M., Breidt, F.J. and Paustian, K. (2005) Agricultural MANAGEMENT impacts on Soil Carbon Storage under Moist and Dry Climatic Conditions of Temperate and Tropical Regions. Biogeochemistry, 72, 87-121.

https://doi.org/10.1007/s10533-004-0360-2

[13] Ngo, K.M., Turner, B.L., Muller-Landau, H.C., Davis, S.J., Larjavaara, M., Hassan, N.F.B.N. and Lum, S. (2013) Carbon Stocks in Primary and Secondary Tropical Forests in Singapore. Forest Ecology and Management, 296, 81-89. https://doi.org/10.1016/j.foreco.2013.02.004

[14] Murthy, I.K., Gupta, M, Tomar, S., Munsi, M., Tiwari, R., et al. (2013) Carbon Sequestration Potential of Agroforestry Systems in India. Journal of Earth Science and Climate Change, 4, 131. https://doi.org/10.4172/2157-7617.1000131

[15] Wei, X.R., Shao, M.G., Gale, W. and Li, L.H. (2014) Global Pattern of Soil Carbon Losses Due to the Conversion of Forests to Agricultural Land. Scientific Report, 4, 4062. https://doi.org/10.1038/srep04062

[16] Fan, S., Guan, F., Xu, X., Forrester, D.I., Ma, W. and Tang, X. (2016) Ecosystem Carbon Stock Loss after Land Use Change in Subtropical Forests in China. Forests, 7, 142. https://doi.org/10.3390/f7070142

[17] Homebegowda, H.C., Van Straaten, O., Kokler, M. and Holscher, D. (2016) On the Rebound: Soil Organic Carbon Stocks Can Bounce Back to near Forest Levels When Agro-Forests Replace Agriculture in Southern India. Soil, 2, 13-23. https://doi.org/10.5194/soil-2-13-2016

[18] Montagini, F. and Nair, P.K.R. (2004) Carbon Sequestration: An Underexploited Environmental Benefit of Agroforestry Systems. Agroforestry Systems, 61-62, 281-295. https://doi.org/10.1023/B:AGFO.0000029005.92691.79

[19] FSI (Forest Survey of India) (2017) India State of Forest Report. Forest Survey of India (Ministry of Environment \& Forests and Climate Change) Kaulagarh Road, Dehradun.

[20] Sahoo, U.K., Singh, S.L., Nundanga, L., Nuntluanga, L., Devi, A.S. and Zothanzama, J. (2018) Climate Change Impacts on Forests and Its Adaptation Study in Mizoram. Technical Report, Mizoram University, Aizawl, 44.

[21] Singh, S. and Dadhwal, V.K. (2009) Manual on Spatial Assessment of Vegetation Carbon Pool of India. Indian Institute of Remote Sensing (National Remote Sensing Centre), Dehradun. 
[22] Harmon, M.E. and Sexton, J. (1996) Guidelines for Measurement of Woody Detritus in Forest Ecosystems. Publication No. 20. U.S. LTER Network, College of Forest Resources, University of Washington, Seattle, Washington DC, 73.

[23] Zanne, A.E., Lopez-Gonzalez, G., Coomes, D.A., Ilic, J., Jansen, S., Lewis, S.L., Miller, R.B., Swenson, N.G., Wiemann, M.C. and Chave, J. (2009) Global Wood Density Database. Dryad Digital Repository.

[24] Clark, D.B., Clark, D.A., Brown, S., Oberbauer, S.F. and Veldkamp, E. (2002) Stocks and Flows of Coarse Woody Debris across a Tropical Rain Forest Nutrient and Topography Gradient. Forest Ecology and Management, 164, 237-248. https://doi.org/10.1016/S0378-1127(01)00597-7

[25] Misra, R. (1968) Ecology Workbook. Oxford and IBH Publishing Co., New Delhi.

[26] Chave, J., Rejou-Mechain, M., Burquez, A., Chidumayo, E., Colgan, M.S., Delitti, W.B.C., Vieilledent, G., et al. (2014) Improved Allometric Models to Estimate the Aboveground Biomass of Tropical Trees. Global Change Biology, 20, 3177-3190. https://doi.org/10.1111/gcb.12629

[27] Hairiah, K., Dewi, S., Agus, F., Velarde, S., Ekadinata, A., Rahayu, S. and van Noordwijk, M. (2010) Measuring Carbon Stocks across Land Use Systems: A Manual. Bogor, Indonesia. World Agroforestry Centre (ICRAF), SEA Regional Office, 155.

[28] Brown, S. (1997) Estimating Biomass and Biomass Change of Tropical Forests: A Primer. FAO Forestry Paper 134, Food and Agriculture Organization, Rome, 55.

[29] Khalid, H., Zin, Z.Z. and Anderson, J.M. (1999) Quantification of Oil Palm Biomass and Nutrient Value in a Mature Plantation: Above-Ground Biomass. Journal of Oil Palm Research, 2, 23-32.

[30] Ali, A., Xu, M.S., Zhao, Y.T., Zhang, Q.Q., Zhou, L.L., et al. (2015) Allometric Biomass Equations for Shrub and Small Tree Species in Subtropical China. Silva Fennica, 49, 1-10. https://doi.org/10.14214/sf.1275

[31] Cairns, M.A., Brown, S., Helmer, E.H. and Baumgardner, G.A. (1997) Root Biomass Allocation in the World's Upland Forests. Oecologia, 111, 1-11. https://doi.org/10.1007/s004420050201

[32] Teissier du Cros, R. and Lopez, S. (2009) Preliminary Study on the Assessment of Deadwood Volume by the French National Forest Inventory. Annals of Forest Science, 66, 302. https://doi.org/10.1051/forest/2009007

[33] Pfeifer, M., Lefebvre, V., Turner, E., Cusack, J., Khoo, M., Chey, V.K., Peni, M. and Ewers, R.M. (2015) Deadwood Biomass: An Underestimated Carbon Stock in Degraded Tropical Forests? Environmental Research Letters, 10, Article ID: 044019. https://doi.org/10.1088/1748-9326/10/4/044019

[34] Walkley, A. and Black, I.A. (1934) An Examination of Degtjareff Method for Determining Soil Organic Matter and a Proposed Modification of the Chromic Acid Titration Method. Soil Science, 37, 29-37. https://doi.org/10.1097/00010694-193401000-00003

[35] Nelson, D.W. and Sommers, L.E. (1982) Total Carbon, Organic Carbon, and Organic Matter. In: Page, A.L., Ed., Methods of Soil Analysis, Part 2, 2nd Edition, Agronomy Monograph 9, American Society of Agronomy and Soil Science Society of America, Madison, 539-594.

[36] Brady, N.C. and Weil, R.R. (2008) The Nature and Properties of Soils. 14th Edition, Pearson Education, London.

[37] IPCC (Intergovernmental Panel on Climate Change) (2006) Agriculture, Forestry 
and Other Land Use. In: Eggleston H.S., Buendia L., Miwa K., Ngara T. and Tanabe K., Eds., 2006 IPCC Guidelines for National Greenhouse Gas Inventories, Prepared by the National Greenhouse Gas Inventories Programme, IGES.

[38] Deng, L., Zhu, G.Y., Tang, Z.S. and Shangguan, Z.P. (2016) Global Patterns of the Effects of Land Use Changes on Soil Carbon Stocks. Global Ecology and Conservation, 5, 127-138. https://doi.org/10.1016/j.gecco.2015.12.004

[39] Schall, P. and Ammer, C. (2013) How to Quantify Forest Management Intensity in Central European Forests. European Journal of Forest Research, 132, 379-396. https://doi.org/10.1007/s10342-013-0681-6

[40] Klanderud, K., Mbolatiana, H.Z.H., Vololomboahangy, M.N., Radimbison, M.A., Roger, E., Totland, O. and Rajeriarison, C. (2010) Recovery of Plant Species Richness and Composition after Slash-and-Burn Agriculture in a Tropical Rainforest in Madagascar. Biodiversity and Conservation, 19, 187-204.

https://doi.org/10.1007/s10531-009-9714-3

[41] Kumar, B.M., George, S.J. and Chinnamanis, S. (1994) Diversity, Structure and Standing Stock of Wood in the Homegardens of Kerala in Peninsular India. Agroforestry Systems, 25, 243-262. https://doi.org/10.1007/BF00707463

[42] Snelder, D.J. (2008) Smallholder Tree Growing in Philippine Back Yards: Homegarden Characteristics in Different Environmental Settings. In: Snelder, D.J. and Lasco, R., Eds., Smallholder Tree Growing for Rural Development and Environmental Services, Springer Science + Business Media, Amsterdam, 37-74. https://doi.org/10.1007/978-1-4020-8261-0_2

[43] Singh, S.L. (2017) Comparative Studies on Carbon Stock and Effectiveness of Carbon Sequestration Potential of Traditional Homegardens and Shifting Cultivation Fallow in Aizawl District of Mizoram. PhD Thesis (Unpublished), Mizoram University, Aizawl, 174.

[44] Poffenberger, M., Barik, S.K., Choudhury, D., Darlong, V, Gupta, V., Patil, S., Ror, I., Singh, I., Tiwari, B.K. and Upadhyay, S. (2006) Forest Sector Review of Northeast India. Community Forestry International, Santa Barbara, CA.

[45] Banik, R.L. (2010) Biology and Silviculture of Muli Bamboo: Melocaena baccifera (Roxb.) Kurz. National Mission on Bamboo Application, New Delhi, 237.

[46] Condes, S. and Del Rio, M. (2015) Climate Modifies Tree Interaction in Terms of Basal Area Growth and Mortality in Monospecific and Mixed Fagussylvatica and Pinussylvestris Forests. European Journal of Forest Research, 134, 1095-1108. https://doi.org/10.1007/s10342-015-0912-0

[47] Ahrends, A., Hollingsworth, P.M., Ziegler, A.D., Fox, J.M., Chen, H., Su, Y. and Xu, J. (2015) Current Trends of Rubber Plantation Expansions May Threatenen Biodiversity and Livelihoods. Global Environmental Change, 34, 48-58.

https://doi.org/10.1016/j.gloenvcha.2015.06.002

[48] Don, A., Schumacher, J. and Freibauer, A. (2011) Impact of Tropical Land-Use Change on Soil Organic Carbon Stocks-A Meta Analysis. Global Change Biology, 17, 1658-1670. https://doi.org/10.1111/j.1365-2486.2010.02336.x

[49] Guan, F., Tang, X., Fan, S., Zhou, J. and Peng, C. (2015) Changes in Soil Carbon and Nitrogen Stocks Followed the Conversion from Secondary Forest to Chinese Fir and Moso Bamboo Plantations. Catena, 133, 455-460.

https://doi.org/10.1016/j.catena.2015.03.002

[50] Van Noordwijk, M., Lawson, G., Soumare, A., Groot, J.J.R. and Hairiah, K. (1996) Root Distribution of Trees and Crops: Competition and/or Complementarity. In: Ong, C.K. and Huxley, P., Eds., Tree-Crop Interactions, CAB International, Oxon, 
319-364.

[51] Yimer, F., Ledin, S. and Abdelkadir, A. (2007) Change in Soil Organic Carbon and Total Nitrogen Contents in Three Adjacent Land Use-Types in the Bale Mountains, Southeast Highlands of Ethopia. Forest Ecology and Management, 242, 337-342. https://doi.org/10.1016/j.foreco.2007.01.087

[52] Sanju, U.M., Jabro, J.D. and Stevens, W.B. (2008) Soil Carbon Dioxide Emission and Carbon Content as Affected by Irrigation Tillage Cropping Systems, and Nitrogen Fertilization. Journal of Environmental Quality, 37, 98-106. https://doi.org/10.2134/jeq2006.0392

[53] Mancinelli, R., Campigilia, E., Di Tizio, A. and Marinari (2010) Soil Carbon Dioxide Emission and Carbon Content as Affected by Conventional and Organic Croppingsystems in Mediterranean Environment. Applied Soil Ecology, 46, 64-72. https://doi.org/10.1016/j.apsoil.2010.06.013

[54] Wang, Z.P., Han, X.G. and Li, L.H. (2008) Effect of Grassland Conversion to Croplands on Soil Organic Carbon in the Temperate Inner Mangolia. Journal of Environmental Management, 86, 529-534.

https://doi.org/10.1016/j.jenvman.2006.12.004

[55] Ketterings, Q.M., Coe, R., van Noordwijk, M., Ambagau, Y. and Palm, C.A. (2001) Reducing Uncertainty in the Use of Allometric Biomass Equations for Predicting Above-Ground Tree Biomass in Mixed Secondary Forests. Forest Ecology and Management, 146, 199-209. https://doi.org/10.1016/S0378-1127(00)00460-6

[56] Chave, J., Andalo, C., Brown, S., Cairns, M.A., Chambers, J.Q., Eamus, D., Folster, H., Fromard, F., Higuchi, N., Kira, T., Lescure, J.P., Nelson, B.W., Ogawa, H., Puig, H., Riera, B. and Yamakura, T. (2005) Tree Allometry and Improved Estimation of Carbon Stocks and Balance in Tropical Forests. Oecologia, 145, 87-99.

https://doi.org/10.1007/s00442-005-0100-x

[57] Schroeder, P. (1994) Carbon Storage Benefits of Agroforestry Systems. Agroforestry Systems, 27, 89-97. https://doi.org/10.1007/BF00704837

[58] Albrecht, A. and Kandji, S.T. (2003) Carbon Sequestration in Tropical Agroforestry Systems. Agriculture, Ecosystems and Environment, 99, 15-27. https://doi.org/10.1016/S0167-8809(03)00138-5

[59] Mutuo, P.K., Cadisch, G., Albrecht, P.C.A. and Verchot, L. (2005) Potential of Agroforestry for Carbon Sequestration and Mitigation of Greenhouse Gas Emissions from Soils in the Tropics. Nutrient Cycling in Agroecosystems, 71, 43-54. https://doi.org/10.1007/s10705-004-5285-6

[60] Kongsager, R., Napier, J. and Mertz, O. (2013) The Carbon Sequestration Potential of Treecrop Plantations. Mitigation and Adaptation Strategies for Global Change, 18, 1197-1213. https://doi.org/10.1007/s11027-012-9417-z

[61] Turner, J., Lambert, M.J. and Johnson, D.W. (2005) Experience with Patterns of Change in Soil Carbon Resulting from Forest Plantation Establishment in Eastern Australia. Forest Ecology and Management, 220, 259-269. https://doi.org/10.1016/j.foreco.2005.08.025

[62] Varamesh, S., Hosseini, S.M., Abdi, N. and Akbarinia, M. (2009) Effects of Afforestation on Soil Carbon Sequestration in an Urban Forest of Arid Zone in Chitgar Forest Park of Tehran. Forest Science, 3, 75-90.

[63] Iqbal, S. and Tiwari, S.C. (2016) Soil Organic Carbon Pool under Different Land Uses in Achanakmar Biosphere Reserve of Chattissgarh, India. Current Science, 110, 771-773.

[64] Jobbagy, E.G. and Jackson, R.B. (2000) The Vertical Distribution of Soil Organic 
Carbon and Its Relation to Climate and Vegetation. Ecological Application, 10, 423-436. https://doi.org/10.1890/1051-0761(2000)010[0423:TVDOSO]2.0.CO;2

[65] Wei, Z., Zhongmin, H.U., Shenggong, L.I., Guo, Q., Yang, H. and Zang, T. (2017) Impact of Land Use Conversion on Soil Organic Carbon Stock in an Agro-Pastoral Ecotone of Inner Mongolia. Journal of Geographical Sciences, 27, 999-1010. https://doi.org/10.1007/s11442-017-1417-1

[66] Jodha, N.S. (1992) Mountain Perspective and Sustainability, a Framework for Development. In: Jodha, N.S., Banskota, M. and Partap, T., Eds., Sustainable Mountain Agriculture, Oxford \& IBM Publishing Co Pvt. Ltd., New Delhi, 41-82.

[67] Negash, M. and Starr, M. (2015) Biomass and Soil Carbon Stocks of Indigenous Agroforestry Systems of the South-East rRift Valley Escarpment, Ethopia. Plant and Soil, 393, 95-107. https://doi.org/10.1007/s11104-015-2469-6

[68] Lenka, N.K., Choudhury, P.R., Sudhishri, S., Dass, A. and Patnaik, U.S. (2012) Soil Aggregation Carbon Build up and Root Zone Soil Moisture in Degraded Sloping Lands under Selected Agroforestry Based Rehabilitation Systems in Eastern India. Agriculture, Ecosystems and Environment, 150, 54-62.

https://doi.org/10.1016/j.agee.2012.01.003

[69] Li, Y., Jiao, J., Wang, Z., Cao, B., Wei, Y. and Hu, S. (2016) Effects of Revegetation on Soil Organic Carbon Storage and Erosion Induced Carbon Loss under Extreme Rainstorms in the Hill and Gully Region of The Loess Plateau. International Journal of Environmental Research and Public Health, 13, 456. https://doi.org/10.3390/ijerph13050456

[70] Kane, E.S. and Vogel, J.G. (2009) Patterns of Total Ecosystem Carbon Storage with Changes in Soil Temperature in Boreal Black Spruce Forests. Ecosystems, 45, 322-335. https://doi.org/10.1007/s10021-008-9225-1

[71] Xi, X., Yang, Z., Cui, Y., Sun, S., Yu, C. and Li, M. (2011) A Study of Soil Organic Distribution and Storage in the Northeast Plain of China. Geoscience Frontiers, 2, 115-123. https://doi.org/10.1016/j.gsf.2011.02.001

[72] Farley, K.A., Kelley, E.F. and Hofstede, R.G.M. (2004) Soil Organic Carbon and Water Retention Following Conversion of Grasslands to Pine Plantations in the Ecuadoran Andes. Ecosystems, 7, 729-739. https://doi.org/10.1007/s10021-004-0047-5

[73] Lemma, B., Kleja, D.B., Nilsson, I. and Olsson, M. (2006) Soil Carbon Sequestration under Different Exotic Tree Species in the Southwestern Highlands of Ethopia. Geoderma, 136, 886-898. https://doi.org/10.1016/j.geoderma.2006.06.008

[74] Chen, S., Wang, W., Xu, W., Wang, Y., Wan, H., Chen, D., Tang, Z., Tang, X., Zhou, G. Xio, Z., Zhou, D., Shangguan, Z., Huang, J., He Jin-Sheng, Wang, Y., Sheng, J., Tang, L., Li, X., Dong, M., Wu, Y., Wang, Q., Wang, Z., Wu, J., Chapin III, S. and Bai, Y. (2018) Plant Diversity Enhances Productivity and Soil Carbon Storage. Proceedings of the National Academy of Sciences, 115, 4027-4032. https://doi.org/10.1073/pnas.1700298114

[75] Bashkin, M.A. and Binkley, D. (1998) Changes in Soil Carbon Following Afforestation in Huwaii. Ecology, 79, 829-833. https://doi.org/10.1890/0012-9658(1998)079[0828:CISCFA]2.0.CO;2

[76] Post, W.M. and Kwon, K.C. (2000) Soil Carbon Sequestration and Land Use Change: Processes and Potential. Global Change Biology, 6, 317-327. https://doi.org/10.1046/j.1365-2486.2000.00308.x

[77] Deng, L., Liu, G.B. and Shangguan, Z.P. (2014) Land-Use Conversion and Changing Carbon Stocks in China's “Grain-for-Green” Program: A Synthesis. Global Change 
Biology, 20, 3544-3556. https://doi.org/10.1111/gcb.12508

[78] Detwiler, R.P. (1986) Land Use Change and Global Carbon Cycle-the Role of Tropical Soils. Biogeochemistry, 2, 67-93. https://doi.org/10.1007/BF02186966

[79] Uhlig, J., Hall, C.A.S. and Nyo, T. (1994) Changing Patterns of Shifting Cultivation in Selected countries in Southeast Asia and Their Effect on the Global Carbon Cycle. In: Dale, V., Eds., Effects of land-Use Change on Atmosphereic $\mathrm{CO}_{2}$ Concentrations, South and Southeast Asia as a Case Study, Springer-Verlag, New York, 145-200. https://doi.org/10.1007/978-1-4613-8363-5_5

[80] Guo, L.B. and Gifford, R.M. (2002) Soil Carbon Stock and Land Use Change: A Meta Analysis. Global Change Biology, 8, 345-360. https://doi.org/10.1046/j.1354-1013.2002.00486.x

[81] Nyawira, S.S., Nabel, J.E.M.S., Don, A., Brovkin, V. and Pongratz, J. (2016) Soil Carbon Response to Land-Use Change: Evaluation of a Global Vegetation Model Using Observational Meta-Analyses. Biogeosciences, 13, 5661-5675. https://doi.org/10.5194/bg-13-5661-2016

[82] Zeigler, A.D., Phelps, J., Yuen, J.Q., Webb, E.L., Lawrence, D., Fox, J.M., Bruun, T.B., Leisz, S.J., Ryan, C.M., Dressler, W., Mertz, O., Pascual, U., Padoch, C. and Koh, L.P. (2012) Carbon Outcomes of Major Land Cover Transition in SE Asia: Great Uncertainities and REDD+ Policy Implications. Global Change Biology, 18, 3087-3099. https://doi.org/10.1111/j.1365-2486.2012.02747.x 